\title{
Rare earth element distribution in the Atlantic sector of the Southern Ocean: The balance between particle scavenging and vertical supply
}

\author{
Hathorne Ed C. ${ }^{1,}$, , Stichel Torben ${ }^{2}$, Brueck Bastian ${ }^{1}$, Frank Martin ${ }^{1}$
}

${ }_{1}^{1}$ GEOMAR Helmholtz Ctr Ocean Res Kiel, Kiel, Germany.

2 Univ Southampton, Ocean \& Earth Sci, Natl Oceanog Ctr Southampton, Southampton, Hants, England.

${ }^{*}$ Corresponding author : Ed C. Hathorne

\begin{abstract}
:
The concentrations of rare earth elements (REEs) in seawater display systematic variations related to weathering inputs, particle scavenging and water mass histories. Here we investigate the REE concentrations of water column profiles in the Atlantic sector of the Southern Ocean, a key region of the global circulation and primary production. The data reveal a pronounced contrast between the vertical profiles in the Antarctic Circumpolar Current (ACC) and those south of the ACC in the Weddell Gyre (WG). The ACC profiles exhibit the typical increase of REE concentrations with water depth and a change in the shape of the profiles from near linear for the light REEs to more convex for the heavy REEs. In contrast, the WG profiles exhibit high REE concentrations throughout the water column with only the near surface samples showing slightly reduced concentrations indicative of particle scavenging. Seawater normalised REE patterns reveal the strong remineralisation signal in the ACC with the light REEs preferentially removed in surface waters and the mirror image pattern of their preferential release in deep waters. In the WG the patterns are relatively homogenous reflecting the prevalence of well-mixed Lower Circumpolar Deep Water (LCDW) that follows shoaling isopycnals in the region. In the WG particle scavenging of REEs is comparatively small and limited to the summer months by light limitation and winter sea ice cover. Considering the surface water depletion compared to LCDW and that the surface waters of the WG are replaced every few years, the removal rate is estimated to be on the order of $1 \mathrm{nmol} \mathrm{m}-3 \mathrm{yr}-1 \mathrm{for} L a$ and $\mathrm{Nd}$. The negative cerium anomalies observed in deep waters are some of the strongest found globally with only the deepest waters in parts of the Pacific having stronger anomalies. These deep waters have been isolated from fresh continental REE inputs during their long journey through the abyssal Indo-Pacific Ocean, which suggests that the high REE concentrations found in the ACC and WG reflect contributions from old deep waters.
\end{abstract}




\section{Highlights}

- Distinct rare earth element profiles across southern boundary of Antarctic Circumpolar Current $\longrightarrow$ Low particle concentrations and strong vertical exchange cause homogenous vertical profiles. Pronounced deepwater $\mathrm{Ce}$ anomalies reflect isolation from new continental sources to seawater.

Keywords : Rare earth elements, Atlantic sector of the Southern Ocean, Weddell Gyre, GEOTRACES 


\section{Introduction}

The isotopic composition of the rare earth element $\mathrm{Nd}$ in seawater is a GEOTRACES key parameter because it is frequently applied as a chemical tracer of present and past ocean circulation (e.g. Piepgras and Wasserburg, 1980; Frank 2002; Piotrowski et al., 2005; Pena and Goldstein 2014). It is clear that the source of rare earth elements (REEs) to seawater is continental from dust, rivers and margin sediments but contributions from these sources are not well quantified, mainly because of poor data coverage in large parts of the global ocean (e.g. Rempfer et al., 2011). A number of studies have recently contributed to filling these data gaps (see Lacan et al., 2012 for the global database before most of these new efforts; Grenier et al. 2013; Haley et al., 2014; Osborne et al., 2014; Molina-Kescher et al., 2014), many of which were conducted within the framework of the international GEOTRACES program, (Singh et al., 2012; Stichel et al., 2012a, b; Chen et al., 2013b; Garcia-Solsona et al., 2014, Goswami et al., 2014). However, not all of these studies reported the complete set of REEs thus not exploring their full potential.

The REEs - defined here by the lanthanide group of elements - have similar chemical properties while their ionic radii decrease with increasing atomic number (e.g. Raymond et al. 2010). This results in a systematic variation of speciation in seawater dominated by complexes with carbonate ions (Chantrell and Byre, 1987). The 
dissolved REEs are mostly found in the 3+ oxidation state and are particle reactive exhibiting nutrient like depth profiles in seawater (e.g. Elderfield, 1988). The element specific complexation with carbonate ions and affinity for negatively charged sites of organic molecules can explain the different concentrations of the REEs in seawater (e.g. Byrne and Kim, 1990). With more free metal ions in seawater, the light REEs (LREE), such as $\mathrm{La}$ and $\mathrm{Nd}$, are preferentially adsorbed to particles compared to heavy REEs (HREE), such as Er and Yb, which are almost entirely bound in stable carbonate complexes (e.g. Byrne and Sholkovitz, 1996). Cerium is exceptional in that it is oxidized, although mediated by microbial activity, to highly insoluble $\mathrm{Ce}(\mathrm{IV}) \mathrm{O}_{2}$ (e.g. Moffett 1990). This preferentially removes Ce from the dissolved phase (operationally defined by filter size) and results in shale (as an approximation of the continental crust composition) normalized Ce concentrations $\sim 10$ times lower than the neighbouring REEs. This "Ce anomaly" is variable throughout the oceans and has been linked to the oxygenation state of seawater (e.g. Nozaki et al., 1999) although there should be a threshold level of low oxygen, at which Ce remains dissolved, which is strongly $\mathrm{pH}$ dependant (de Baar et al., 1985). The Ce anomaly has also been related to the successive removal of $\mathrm{Ce}(\mathrm{IV}) \mathrm{O}_{2}$ over time as a function of the age of water masses (e.g. German and Elderfield, 1990b).

Yttrium (Y), also present in the $3+$ oxidation state, is often grouped together with the REEs because it has an ionic radius and a chemical behaviour very close to that of Ho (Shannon 1976). Fractionation of $\mathrm{Y}$ and Ho has been observed in hydrothermal systems and marine sediments (e.g. Bau 1996) and has been related to the preferential sorption of Ho (and REEs) onto Fe hydroxides in marine (Bau et al., 1996) and soil settings (Thompson et al., 2013). Generally, a relatively small fraction of the REEs found in seawater is bound to particles with the particulate portion of $\mathrm{Nd}$ being 4-5 times that of Yb (Bertram and Elderfield, 1993; Sholkovitz et al. 1994; Alibo and Nozaki, 1999). Many studies have concluded that Mn and Fe oxides are the most important particulate phases carrying REEs (Sholkovitz et al., 1994; Bau and Koschinsky, 2006, 2009) although potentially important roles of diatoms (Akagi et al., 2011) and organic ligands (e.g. Haley et al., 2014) have recently been suggested. For the REEs to be exported from the surface and be remineralised at depth similar to nutrients, the size of the particles is also important. Smaller suspended particles advect REEs through the ocean while only larger aggregates of sinking particles, such as faecal pellets contribute to the vertical flux (Jeandel et al., 1995). Studies 
employing ultrafiltration $(0.04 \mu \mathrm{m})$ report REE concentrations similar to unfiltered or conventionally $(0.4 \mu \mathrm{m}$ ) filtered samples (Alibo and Nozaki 1999, 2000, 2004; Nozaki and Alibo 2003a) suggesting a negligible colloidal component. However, recent sorption experiments using ultrafiltration to $<30$ and $<3 \mathrm{kDa}$ suggest that this may not always be the case (Schijf and Zoll, 2011). The combined properties described above make the $\mathrm{Y}$ and REE compositions of seawater a powerful tool to investigate the inputs and cycling of trace metals in seawater.

The cycling of trace metals in the Southern Ocean is of interest because it is amongst the most productive areas of the global ocean and has been recognized as vitally important for global climate and the carbon cycle (e.g. Sigmann et al., 2010). For example, changes in the biological carbon pump associated with diatom productivity have been related to atmospheric $\mathrm{CO}_{2}$ changes on glacial-interglacial time scales (e.g. Martinez-Garcia et al., 2014). Changes in nutrient utilization in the distinct zones of the Antarctic Circumpolar Current (ACC) have been modelled to have distinct effects on primary productivity and global atmospheric $\mathrm{CO}_{2}$ drawdown (e.g. Marinov et al., 2006). Therefore the influence of the modern biological pump on the trace metal distribution in this region is important for our understanding of the processes driving climatic changes. Here we present REE and Y concentration data for seawater profiles that cover the Subantarctic and Antarctic zones near the Zero Meridian, the Weddell Gyre, and the Drake Passage. These data clearly reflect the drastic changes in the particulate vertical flux of REEs across the "biogeochemical divide" (Marinov et al., 2006) between the Subantarctic and Antarctic Zones of the ACC.

\subsection{Hydrography}

The samples analysed here, and their hydrographic context, were described in detail in Stichel et al., (2012a) and therefore the hydrography is only briefly summarised here. The hydrography of the study area and its variability have been the subject of many dedicated studies (e.g. Orsi et al., 1995; Stramma and England, 1999; Orsi et al., 2002; Meijers et al., 2010) and the reader is referred to these for more detail. The circulation in the Atlantic sector of the Southern Ocean (Figure 1) is dominated by the eastward flowing ACC, which is bounded to the north by the Subtropical Front (STF) and to the south by the boundary (BDY) with the Weddell Gyre (WG). The ACC 
extends from the surface to abyssal depths and is divided into Upper Circumpolar Deep Water (UCDW) and Lower Circumpolar Deep Water (LCDW) with neutral densities for CDW of $27.55 \mathrm{~kg} / \mathrm{m}^{3} \leq \gamma \mathrm{n} \leq 28.27 \mathrm{~kg} / \mathrm{m}^{3}$. Southward flowing North Atlantic Deep Water (NADW) enters the south western Argentine Basin as part of the Deep Western Boundary Current before it merges eastward with the ACC (Stramma and England, 1999). Along this pathway of the ACC, NADW mixes with less dense waters returning from the southeast Pacific and the Indian Ocean to form UCDW but NADW is clearly identified by its characteristic deep salinity maximum within LCDW in the entire Atlantic sector of the Southern Ocean (Reid and Lynn, 1971).

Antarctic Intermediate Water (AAIW), marked by relatively high dissolved oxygen and low salinities with a neutral density range of $27.13 \mathrm{~kg} / \mathrm{m}^{3} \leq \gamma \mathrm{n} \leq 27.55 \mathrm{~kg} / \mathrm{m}^{3}$ (Whitworth III and Nowlin, 1987), originates from cooled surface waters of the ACC and is subducted northward at the Polar Front (Fig. 1).

Next to the Antarctic continent the WG circulates cyclonically in the Weddell Sea (WS) and is fed by UCDW and LCDW from the ACC flowing in at intermediate depths forming the water mass commonly referred to as Warm Deep Water (WDW). Above WDW, Antarctic Surface Water (AASW) periodically gains density by brine rejection during sea ice formation. Along the continental slopes of the WS these dense and cold surface waters sink down and mix with WDW. The fraction of these waters dense enough to reach the bottom forms the Weddell Sea Bottom Water (WSBW), which is characterized by neutral densities of $\gamma \mathrm{n} \geq 28.40 \mathrm{~kg} / \mathrm{m}^{3}$ (Carmack and Foster, 1975). The less dense parts mix with WDW and form the Weddell Sea Deep Water (WSDW) which is the densest water mass originating in the WS exported to many parts of the world ocean as AABW $\left(28.40 \mathrm{~kg} / \mathrm{m}^{3} \geq \gamma \mathrm{n} \geq 28.27 \mathrm{~kg} / \mathrm{m}^{3}\right.$ (e.g. Orsi et al., 1999, 2002; Heywood and King, 2002; Klatt et al., 2005 and references therein). About $60 \%$ of the AABW in the Southern Ocean forms in the western WS with the remainder produced in the Amery Ice shelf region, the Ross Sea and west of Prydz Bay (Gordon, 1971; Orsi et al., 1999; Stramma and England, 1999; Meijers et al., 2010). Orsi et al. (1999) pointed out that AABW is not circumpolar because it is so dense that it is restricted to certain areas in the Atlantic sector, such as the Argentine Basin. The bottom water of southern origin that covers the remainder of the Atlantic sector of the Southern Ocean is less dense LCDW, often termed ACC bottom water (Orsi et al., 1999). 


\section{Methods}

During Polarstern Expedition ANTXXIV/3 (PS71) in February and March 2008 an extensive GEOTRACES sampling campaign was conducted in the frame of the International Polar Year (IPY). The cruise track (GIPY5) formed a transect from South Africa along the Greenwich (zero) meridian from $52^{\circ} \mathrm{S}$ to the ice shelf before crossing the Weddell Sea and Drake Passage. The exact same samples analysed here were used for the studies of Stichel et al. (2012a,b), where they are described in detail.

Along the cruise track a full nutrient, dissolved inorganic carbon and alkalinity dataset has been obtained (van Heuven et al., 2011). For this cruise, full water depth profiles have also been analysed for $\mathrm{Al}$ and Mn concentrations (Middag et al., 2011a, b), Fe concentrations (Klunder et al., 2011), organic complexation of Fe (Thuróczy et al., 2011), Zn concentrations (Croot et al., 2011), and Ba concentrations (Roeske and Rutgers van der Loeff, 2014) and radiogenic isotope compositions of $\mathrm{Nd}$ and $\mathrm{Hf}$ (Stichel et al., 2012a,b), as well as and ${ }^{234}$ Th activities (Rutgers van der Loeff et al., 2011). The French "Bonus Good Hope" GEOTRACES cruise GIPY4 with the RV Marion Dufresne (MD166) sampled the same section from Cape Town to $57^{\circ} \mathrm{S}$ just 2 weeks after the Polarstern cruise. Samples from that cruise have been analysed for REE concentrations and Nd isotope compositions by Garcia-Solsona et al. (2014) and a detailed comparison of the cross-over stations occupied by both cruises is presented here.

Surface water samples were collected using a towed steel fish or the seawater intake system during transit time, pumping seawater from 2-5 m water depth (see Stichel et al. 2012b for details). Deeper samples were collected from Niskin bottles mounted on a CTD-rosette (see Stichel et al. 2012a for details). All samples were filtered through $0.45 \mu \mathrm{m}$ Millipore ${ }^{\circledR}$ or Supor ${ }^{\circledR}$ filters into acid cleaned 2L LDPE bottles and acidified to $\mathrm{pH} \sim 2$ using double distilled concentrated nitric acid within 12 hours after collection.

The concentrations of Y and all REEs were analysed by ICP-MS (Agilent 7500-CE) using an ESI SeaFAST online-preconcentration system following a method adapted from Hathorne et al. (2012). The main modifications to improve the method were the use of an $8 \mathrm{~mL}$ sample loop and the preparation of calibration standards with a mixed 
REE solution of a seawater-like composition in a natural seawater matrix. Trace metals, including the REEs, were removed from this seawater matrix by $\mathrm{FeOOH}$ coprecipitation. Although the original method performed satisfactorily during the GEOTRACES intercalibration exercise (van de Flierdt et al., 2012), the improved method offers significantly better precision for many elements while still consuming only a small amount of sample (only $11 \mathrm{~mL}$ required per analysis). The precision and accuracy of the method during data acquisition for this study was assessed by repeated analysis of GEOTRACES inter-calibration samples obtained at the Bermuda time series station; BATS $15 \mathrm{~m}$ and 2000m (Table 1). These data are presented along with the consensus values from the GEOTRACES intercalibration exercise (van der Flierdt et al., 2012) in Table 1. Since the publication of the original SeaFAST method some studies have published offline methods using the Nobias-chleate PA-1® resin to preconcentrate REEs from seawater before ICP-MS analysis (Rousseau et al., 2013; Hatje et al., 2014). In other studies the traditional method of FeOOH co-precipitation has been preferred (Pahnke et al., 2012; Zheng et al., 2014). Hatje et al. (2014) used $70-80 \mathrm{~mL}$ of sample and obtained relative standard deviations $(2 \sigma)$ for five replicate analyses of a Pacific Deep Water reference sample between $8.4 \%$ for La and $1.3 \%$ for $\mathrm{Nd}$ (personal communication 2014). Zheng et al. (2014) used $100 \mathrm{~mL}$ samples and obtained a precision of $3 \%(1 \sigma)$ using a three element (Ce, $\mathrm{Nd}$ and $\mathrm{Yb}$ ) spike isotope dilution technique. Rousseau et al. (2013) employed a ten-element spike isotope dilution technique and obtained a precision of around $2 \%(2 \sigma)$ on two measurements of $250 \mathrm{~mL}$ of a BATS $2000 \mathrm{~m}$ sample. Pahnke et al. (2012) used an eight-element spike (not spiking La and $\mathrm{Lu}$ ) isotope dilution technique to measure the REEs in 50$100 \mathrm{~mL}$ aliquots and obtained an external reproducibility $(2 \sigma)$ better than $3 \%$, except for $\mathrm{Ce}$, which was $3.8 \%$. Clearly our method that gives an estimated external precision $(2 \sigma)$ ranging from $4 \%$ to $18 \%$ (Table 1 ), consumes at least 5 times less sample, and requires no additional sample preparation, compares favourably with these methods. Additional improvements have been made to the measurement technique since most of the data presented here were measured (Table 1: station 113, 1000 m sample by Time Resolved Analysis; also Osborne et al. this volume), which now enable the seaFAST online preconcentration technique to achieve a precision similar to the other methods mentioned above while still consuming significantly less sample material. 


\section{Results}

Yttrium and REE concentrations in the $<0.45 \mu \mathrm{m}$ filtered seawater generally increase with water depth (Figure 2), for example Lu increases from $0.4 \mathrm{pmol} / \mathrm{kg}$ in the surface waters to $1.4 \mathrm{pmol} / \mathrm{kg} \mathrm{Lu}$ at $4500 \mathrm{~m}$ depth. Over the same depth range $\mathrm{La}$ and $\mathrm{Y}$ concentrations increase from 12 and $90 \mathrm{pmol} / \mathrm{kg}$ to 45 and $190 \mathrm{pmol} / \mathrm{kg}$, respectively. The shape of the increase with depth varies from near linear for LREEs to more convex for HREEs with relatively constant HREE concentrations in intermediate and deep waters (Figure 2). The vertical distribution (or profile) of the HREEs is very similar to that of the hard part (i.e. skeletal opal or $\mathrm{CaCO}_{3}$ ) forming nutrients silicic acid (silicate) and alkalinity (Figure 3). Similar to silicate, the depth distribution of the REEs evolves along the zero meridian section in that the difference between the surface and deep water concentrations decreases southward. The stations in the Weddell Gyre $(131,161,193)$ exhibit virtually constant silicate concentrations below $1000 \mathrm{~m}$ and constant alkalinity below $500 \mathrm{~m}$. Similarly, the REE concentrations are high and constant in intermediate and deep waters within the WG. The Drake Passage station (241) has an alkalinity profile (and silicate, not shown) intermediate between the WG stations and those from within the ACC near the Zero meridian $(101,104)$ and also exhibits REE concentration profiles intermediate between the WG and ACC extremes.

\section{Comparison of crossover data}

One central component of the GEOTRACES program is to ensure that crossover stations between cruises are sampled at similar depths and the resulting data are compared as a cross calibration exercise while also providing some information on the short term variability of some parameters. The Southern Ocean cruises of the IPY achieved this and stations 101, 104 and 113 were sampled at almost identical locations as stations S2, S3, and S4 from the "Bonus Good Hope" GIPY4 cruise, for which REE concentrations were published by Garcia-Solsona et al. (2014). The GIPY4 cruise sampled these locations only 2 weeks after the Polarstern cruise and the crossover data, measured following different pre-concentration techniques, generally agree within uncertainties (Figure 4 and supplementary figure 1). In a few instances there are differences in REE concentrations at similar depths but in most cases careful comparison of the silicate data suggests that these differences are related 
to real short-term variations of the water masses sampled. A good example is station 113 which shows higher silicate concentrations and slightly elevated LREE concentrations compared to GIPY4 station "super 4" at intermediate depths (Figures 3 \& 4). The deepest sample of GIPY4 station "super 3" has much lower REE concentrations than all other samples at such depths. While near bottom scavenging of $\mathrm{Nd}$ has been reported in the Pacific sector of the Southern Ocean (Carter et al., 2012), removal of essentially half the bottom water REE inventory, including Ce (Figure 4), within two weeks seems unlikely. Instead this most likely indicates a leaking Niskin bottle, but this cannot be independently confirmed as nutrient concentrations were not measured on the same bottle.

\section{Discussion}

\subsection{Particle scavenging and REE patterns}

Given that REEs in seawater originate from continental sources, it is common practice to normalise seawater REE concentrations to those of shale as an approximation of the average composition of the continental crust (e.g. Elderfield and Greaves 1982; Alibo and Nozaki, 1999). This approach reveals the seawater REE fractionation from the continental source through preferential scavenging of LREEs compared to HREEs, as well as the enhanced removal of Ce (Figure 5). These typical seawater REE patterns have been modelled to result from the combined effects of HREEs preferentially forming stable carbonate complexes and the affinity of $\mathrm{REE}^{3+}$ to negatively charged sites of organic molecules (e.g. Byrne and Kim, 1990). The patterns therefore indicate significant interaction of the REEs with particles since their introduction into seawater. The unique oxidation of $\mathrm{Ce}(\mathrm{III})$ to insoluble $\mathrm{Ce}(\mathrm{IV}) \mathrm{O}_{2}$ and the resulting Ce anomalies will be discussed separately below (section 4.4).

The similarity of the HREE concentration depth profiles with those of the hard part forming nutrients silicate and alkalinity (Figs. 2, 3, and supplementary Fig. 2) suggests that the REEs are removed from surface waters by biological productivity and are then released again in deeper waters where the sinking hard parts and organic matter dissolve. The correlation coefficients $\left(R^{2}\right)$ between phosphate concentrations and the REEs (excluding Ce) in our dataset range from 0.47 to 0.66 for the LREE and MREE (from La up to and including Dy), but increase to 0.71 to 0.81 for the HREEs (Ho to Lu, also including Y). A very similar pattern is observed for the correlations with nitrate concentrations. The correlation coefficients with silicate concentrations 
and in particular total alkalinity are higher and differ less between the REEs (Fig. 3 and supplementary Fig. 2). LREEs and MREEs have $R^{2}$ values ranging from 0.88 to 0.95 with silicate and from 0.8 to 0.88 with alkalinity. The HREEs (including Y) have $R^{2}$ values ranging from 0.91 to 0.96 with silicate and 0.87 to 0.93 with alkalinity.

The strong correlation of REEs with alkalinity is not surprising given that the REEs in seawater are mainly, the HREEs almost entirely, present in the form of stable carbonate complexes (e.g. Byrne and Sholkovitz, 1996). Using the "CO2sys" macro (Pierrot et al., 2006) we calculated the other carbonate system parameters from the alkalinity, Dissolved Inorganic Carbon (DIC) and nutrient data (van Heuvan et al., 2011). Comparison with these calculated parameters reveals that alkalinity is most strongly correlated with REE concentrations with Lu yielding $R^{2}$ values of $-0.83,0.91$, 0.96 and 0.92 with $\mathrm{CO}_{3}{ }^{2-}, \mathrm{HCO}_{3}$, silicate, and alkalinity, respectively. We will not try to interpret these subtle differences but it is clear that the HREE most closely resemble the distribution of hard part nutrients while the LREE are more particle reactive (e.g. Byrne and Sholkovitz, 1996). Similar observations have been made in the Arabian Sea and western Indian Ocean (German and Elderfield, 1990a; Bertram and Elderfield, 1993).

The mechanism behind the correlation of REEs with silicate and alkalinity has been discussed since the earliest studies of seawater REEs (Elderfield and Greaves, 1982; de Baar et al., 1985). The central question is whether the REEs are incorporated into the opal and $\mathrm{CaCO}_{3}$ crystals or adsorbed to associated phases like Fe-Mn oxideshydroxides? Based on leaching of sediment trap material, Akagi et al. (2011) suggested that opal is a significant carrier of HREEs. However, leaching experiments on sediments have shown that factors such as exposure time and differences in sample mass or reagent volume can result in remarkably different results for the REEs (Wilson et al., 2013). Thus, until the REE composition of opal is measured directly the exact role of diatoms in oceanic REE cycling will remain uncertain. Hegner et al. (2007) studied particles in the Atlantic sector of the Southern Ocean and found that bloom samples with the highest particle concentrations and high biogenic opal content (mainly diatoms), had relatively low Nd concentrations. Garcia-Solsona et al. (2014) found apparent partition coefficients between particulate and dissolved REEs to be higher for the LREE than the HREE in this region. The short term decoupling of REE concentrations from nutrients (including silicate) during a bloom event has also been documented in the sub-arctic Pacific (Hara et al., 2009). During an iron fertilisation 
experiment only the LREE were noticeably depleted and concentrations returned to pre-bloom levels within 10 days while nutrient concentrations continued to decline (Hara et a., 2009). All this is evidence for the well known greater affinity of the LREEs for particles (e.g. Sholkovitz et al., 1994; Tachikawa et al., 1999).

The different shapes of the REE depth profiles have been modelled to result from different processes: vertical profiles of LREEs that are near linear result from irreversible scavenging while HREE profiles that are convex result from a nutrient like behaviour with uptake in the mixed layer and remineralisation at depth (Oka et al., 2009). A reversible scavenging process in which adsorption onto particles is in balance with desorption closely approximates the changes in profile shapes across the REE series with a systematic change in partition coefficients between LREEs and HREEs (Oka et al., 2009). In the WG even the LREE profiles are flat below $1000 \mathrm{~m}$ (station 161) or almost homogenous (station 131) suggesting that additional processes play a role at these locations.

To better distinguish relative differences between the REEs, normalisation to seawater is often preferred to PAAS normalisation as it reveals even subtle differences in the REE patterns of seawater samples. Here we have chosen LCDW to normalise to as this water mass forms the deep core of the ACC and upwells into the Wedell Gyre (e.g. Usbeck et a. 2002). For normalisation we used average LCDW values (Table 1) from stations 113 and 131 and data from Garcia-Solsona et al. (2014). The LDCW normalised patterns (Figure 6) of stations 101, 104 and 241 clearly indicate preferential removal of LREE in surface waters. The samples closest to the sea floor taken $100 \mathrm{~m}$ from the bottom, are essentially characterised by mirror image patterns of the surface waters at stations 101 and 104 suggesting preferential release of LREE during remineralisation near the seafloor and/or release from sediments. The deepest sample at station 241 is only slightly enriched compared to LCDW suggesting that intense mixing at this location removed any remineralisation/sedimentary signal. The LCDW-normalised patterns for the stations in the WG $(131,161,193)$ reveal that the comparably weak removal of REEs from the upper water column affects all REEs in a similar way. The LCDW-normalised patterns of deeper waters in the WG mainly reflect the homogenous water column profiles of all the REEs with only the deepest samples exhibiting small enrichments in the LREEs. This may reflect a small input from sediments, in particular at station 131, which exhibits a significant Ce enrichment below 2000m (Figure 6, Section 4.4). 
Given that these depths are occupied by AABW the signatures of subtle sedimentary inputs may have been acquired on the shelf during the process of AABW formation. $\mathrm{AABW}$ was also found to have less radiogenic $\mathrm{Nd}$ isotopic compositions than $\mathrm{CDW}$ at these stations suggesting an eastern Antarctic source (Stichel et al., 2012a). Similarly unradiogenic results were obtained near station 131 at GIPY4 station super 5 (Garcia-Solsona et al., 2014). Additionally, the particulate REE pattern of the AABW sample at this location was shale like indicating a fresh continental source of these particles (Garcia-Solsona et al., 2014).

\subsection{Meridional variability of REE water column profiles}

Crossing the different zones and frontal systems of the ACC, Rutgers van der Loeff et al. (2011) documented variations in the dissolved ${ }^{234} \mathrm{Th} /{ }^{238} \mathrm{U}$ and inferred ${ }^{234} \mathrm{Th}$ fluxes associated with biogenic particles. In the zones of the ACC including the SAF and PF until about $52^{\circ} \mathrm{S}$ the surface waters are depleted in ${ }^{234} \mathrm{Th}$ indicating a strong export flux. The REE profiles at stations 101, 104 and 113 are consistent with this pattern in that they show a pronounced depletion in surface waters despite upwelling of deeper waters enriched in REEs and/or vertical mixing. Between $54^{\circ} \mathrm{S}$ and $59^{\circ} \mathrm{S}$ surface water

${ }^{234} \mathrm{Th}$ is at equilibrium and high concentrations of dissolved $\mathrm{Fe}$ and $\mathrm{Mn}$ suggest little export and low algal abundances (Rutgers van der Loeff et al., 2011). The slope of the REE increase in the combined dataset of this study and that of Garcia-Solsona et al. (2014), here shown as the change of $\mathrm{Nd}$ concentration with depth or $\Delta[\mathrm{Nd}]$ in pmol/100m (calculated using all available data at each station, excluding only the deepest sample from station S3), reveals a sharp transition occurring near $54^{\circ} \mathrm{S}$ (Figure 7). This change marks a biogeochemical divide, south of which particle scavenging and REE export are limited by light and seasonal sea ice for large parts of the year. At station 131 essentially invariant REE depth profiles are a consequence of a combination of very low particle concentrations and advection of CDW into the gyre. Low particle fluxes have also been deduced from a sediment trap study although ${ }^{234} \mathrm{Th}$ profiles suggested shallow remineralisation of significant opal and POC fluxes (Usbeck et a. 2002). Hegner et al. (2007) analysed samples from multiple years and generally found low particle concentrations in the WG but also some samples with very high concentrations associated with plankton blooms. At station 131 only the REEs of the very surface water are distinguishable from LCDW (Figure 6). The WG 
is particularly interesting in this respect given that it is almost exclusively fed by upwelling CDW into the gyre circulation (e.g. Usbeck et a. 2002). This is also evident in the average $\mathrm{Nd}$ isotopic signature of -8.5 in the $\mathrm{WG}$, which is indistinguishable from CDW (Stichel et al. 2012a, b).

Most likely strong vertical mixing causes homogenous REE concentrations at station 131. Hoppema et al (1999) calculated the surface water layer in the WG to be replaced every 3 years based on the entrainment of Warm Deep Water. Geibert et al. (2002) inferred an approximate rate of upwelling in the WG of $55 \mathrm{~m} / \mathrm{yr}$ based on actinium isotopes. At stations 131 and 193 the REEs are depleted at the surface by approximately $15 \%$, whereas at station 161 this depletion amounts to $20 \%$ (Figure 6). Even though the blooms that occur in this area are relatively short lived events that remineralise at very shallow depths (e.g. Usbeck et a. 2002) they can remove $20 \%$ of the REEs from surface waters before the resupply of freshly upwelled LCDW destroys this signal. Considering the depletion of surface REE concentrations and a water residence time of 2-3 years ((surface $\left.\mathrm{pmol} / \mathrm{m}^{3}-\mathrm{LCDW} \mathrm{pmol} / \mathrm{m}^{3}\right) / 2$ years) requires a removal rate for $\mathrm{La}$ and $\mathrm{Nd}$ on the order of $1 \mathrm{nmol} \mathrm{m}^{-3} \mathrm{yr}^{-1}$, which could deplete the entire REE inventory in 25-30 years if there was no resupply from below. More precise estimates of removal fluxes would require higher resolution sampling to determine the thickness of the depleted surface layer.

In contrast to the WG where LREE and HREE profiles are similar, the REE profiles in the ACC suggest irreversible scavenging of the LREEs and a nutrient like behaviour of the HREEs (Oka et al., 2009). Either the stronger particle scavenging has the effect of changing the shape of the REE depth profiles or there are different types of particles involved in the scavenging north and south of the biogeochemical divide near the ACC boundary. The latter is likely given the differences in pigments observed in the area (Le Moigne et al., 2013), the higher concentrations of Fe binding ligands south of the boundary (Thuroczy et al., 2011), and the inferred shallow remineralisation in the WG (Usbeck et a. 2002). The type of plankton varying with latitude in the ACC is thought to be responsible for the maximum of organic $\mathrm{C}$ export occurring north of the peak in silica export (Ito et al., 2005). North of the divide vertical stratification of the water column may also play a role in controlling the shape of the REE depth profiles (see section 4.3 below). In support of this the $\mathrm{Nd}$ concentration profiles from station SAVE 271 in the South Atlantic (Jeandel, 1993) show a marked increase with depth until NADW is reached near $2500 \mathrm{~m}$. Below this 
depth the $\mathrm{Nd}$ concentration was found to be constant at around $27 \mathrm{pmol} / \mathrm{kg}$ in the LCDW and the WSDW (Jeandel, 1993), very similar to the values in the deep waters and the WG profiles.

South of $59^{\circ} \mathrm{S}$ the ${ }^{234} \mathrm{Th}$ data indicate the strongest export related to an ice edge bloom occurring in the region early in southern summer (Rutgers van der Loeff et al., 2011). However, the REE profiles and LCDW normalised patterns at station 161 exhibit a relatively small remineralisation signal (preferential LREE removal in surface and release at depth) compared with the ACC stations (Figure 6). The remineralisation signal at station 161 is comparable to that in the Weddell Sea (Station 193) where ${ }^{234} \mathrm{Th}$ data were close to equilibrium. This discrepancy is most likely the result of different particle affinities and hence residence times of Th and the REEs. Thorium is probably the most particle reactive element in seawater and hence will produce a large signal with one algal bloom, but significant ingrowth will occur over just a few months (e.g. Rutgers van der Loeff et al., 2011). At the same time, the REEs provide a signal integrating a few years and may provide a better estimate of the mean particle export in a region.

\subsection{Factors controlling the slopes of REE depth profiles globally}

Given that there are significantly more data for seawater $\mathrm{Nd}$ concentrations than for the other REEs globally, our discussion will focus on the changes of $\mathrm{Nd}$ concentrations with water depth $(\Delta[\mathrm{Nd}])$ (section 4.2). The strongest [Nd] gradients of $>1 \mathrm{pmol} / 100 \mathrm{~m}$ were found off Japan (upper 800m, Alibo and Nozaki, 1999), the upper water column off the Niger River delta in W. Africa (Bayon et al., 2011), the South China Sea (Alibo and Nozaki, 2000) and the tropical NW Pacific (Piepgras and Jacobsen, 1992). This suggests a potential role for the proximity to continental margins and related particle inputs although all $\Delta[\mathrm{Nd}]$ values discussed reflect increases with depth. Values of $\Delta[\mathrm{Nd}]$ between 0.4 and $0.7 \mathrm{pmol} / 100 \mathrm{~m}$, similar to those observed in the Sub-Antarctic Zone and the ACC (Figure 7), were found in the N Atlantic (Elderfield and Greaves 1982), in the Pacific from the Gulf of Alaska (Haley et al., 2014) and the NW Pacific (Piepgras and Jacobsen, 1992) to the western, equatorial and south west Pacific (Zhang and Nozaki, 1996; Wang and Yamada, 2007; Grenier et al., 2013; Molina-Kescher et al., 2014), and the Indian Ocean (Bertram and Elderfield, 1993). Values of $\Delta[\mathrm{Nd}]$ near $0.4 \mathrm{pmol} / 100 \mathrm{~m}$ and below were 
found in the Arabian Sea (German and Elderfield, 1990a), in the N Pacific (Shimizu et al., 1994), in the eastern equatorial Pacific (Grasse et al., 2012), in the south east Pacific (Molin-Kescher et al., 2014) and in the eastern Pacific sector of the Southern Ocean (Carter et al., 2012). This suggests that lower $\Delta[\mathrm{Nd}]$ values are generally associated with higher productivity areas or water masses that travelled through such areas.

The assumption of a linear increase in [Nd] with depth is not always valid. A marked break in slope, similar to nutrients, occurs off Japan where $\Delta[\mathrm{Nd}]$ is 1.33 in the upper $800 \mathrm{~m}$ and then 0.36 below 1000m (Alibo and Nozaki, 1999). In contrast, near Bermuda in the Sargasso Sea the $\Delta[\mathrm{Nd}]$ is 0.39 in the upper $1000 \mathrm{~m}$, then effectively zero $(0.04 \mathrm{pmol} / 100 \mathrm{~m})$ from $1000 \mathrm{~m}$ to $3000 \mathrm{~m}$, before a near linear $\Delta[\mathrm{Nd}]$ of 0.6 prevails below (Pahnke et al., 2012). This suggests a role of advection in controlling the $\Delta[\mathrm{Nd}]$ given that the body with the nearly constant concentrations corresponds to NADW. Invariant REE concentrations with depth, such as those from the WG, have been found below 1000m in the Andaman Sea in the eastern Indian Ocean where the water column is homogenous for all measured properties including temperature and salinity (Nozaki and Alibo, 2003a). In this case, the well homogenised water column was attributed to efficient vertical mixing of the deep waters in this semi-enclosed basin (Nozaki and Alibo, 2003a). Sholkovitz and Schneider (1991) reported remarkably constant REE concentrations in the upper $500 \mathrm{~m}$ and $200 \mathrm{~m}$ (only upper 200m sampled) in the Sargasso Sea in different years. Although this homogenized zone extended to depths greater than the mixed layer, which was some 50-100m deep at that time, the decrease of temperature in the upper $500 \mathrm{~m}$ was relatively weak. These examples demonstrate that the absence of a strong stratification and low particle fluxes, or most likely a combination of both, is linked to the development of homogenous REE depth profiles such as in the WG. However, to obtain high REE concentrations and a homogenous depth profile the remineralisation of terrigenous material from the Himalayan rivers was invoked in the Bay of Bengal (Nozaki and Alibo, 2003a). The potential origin of the high REE concentrations in the WG is discussed below (section 4.5) but without more detailed studies of REE particle dynamics in these settings, it is not possible to unambiguously distinguish the relative importance of low reversible scavenging onto particles from strong vertical mixing and/or advection for the development of homogenous depth profiles. 


\subsection{Cerium anomalies in the Southern Ocean}

The Ce anomalies in the Atlantic sector of the Southern Ocean become stronger with depth which is expected for this oxygenated oceanic water column (Figure 8). In the WG and interestingly also in the Drake Passage the Ce anomalies are relatively pronounced at the surface (values < 0.15) and even stronger at depth. Table 2 shows that these Ce anomalies are amongst the strongest found in the global ocean with only the deepest waters in parts of the Pacific having stronger anomalies. Once Ce oxide forms it is hard to dissolve and $\mathrm{Ce}$ is only released under reducing conditions like found in anoxic basins (e.g. Schijf et al., 1993). Cerium oxidation kinetics are relatively slow and the $\mathrm{Ce}$ anomaly $\left(\mathrm{Ce} / \mathrm{Ce}^{*}\right)$ in $\mathrm{Mn}-\mathrm{FeOH}$ crusts, representative of the main sink for REEs from seawater, has been shown to be related to the growth rate of crusts (e.g. Bau et al., 2014). In seawater a general relationship with water mass age has been observed with the strongest Ce anomalies being found in old deep old Pacific waters (German et al, 1995; Table 2). Comparison with the natural ${ }^{14} \mathrm{C}$ distribution of GLODAP (Key et al., 2004) reveals that the isolation from fresh REE input is not directly related to ventilation age as ventilation can occur without supply of REEs. Studies of particulate REEs have suggested that Ce oxidation occurs in the upper water column (e.g. Tachikawa et al., 1999). This led to the suggestion that the strong $\mathrm{Ce}$ anomaly in the deep Pacific results from the preferential release of the neighbouring elements La, Pr and Nd (Alibo and Nozaki, 1999). Table 2 shows this may indeed be the case for the deep Pacific samples but the absolute Ce concentration of $2.18 \mathrm{pmol} / \mathrm{kg}$ in the Drake Passage is one of the lowest values found globally. This means that the strong $\mathrm{Ce}$ anomalies observed in the Southern Ocean result from removal of $\mathrm{Ce}$ and is perhaps characteristic of the deep water feeding into the CDW, which return from the Pacific and pass through the Drake Passage (e.g. Schmitz 1995). This strong Ce/Ce* is also advected and well mixed around the Antarctic within the $\mathrm{ACC}$ as this strong $\mathrm{Ce} / \mathrm{Ce}^{*}$ has also been found deep waters from the Indian sector of the Southern Ocean (Table 2; Nozaki and Alibo, 2003b). This suggests that despite the slight indications of some fresh sedimentary inputs to $\mathrm{AABW}$ (section 4.1) the $\mathrm{Ce} / \mathrm{Ce}^{*}$ is quasi-conservative in the deep waters of the Southern Ocean and reflects the long isolation from fresh continental REE sources.

\subsection{Source of high REE concentrations in the Southern Ocean}


The REEs are supplied to seawater from continental sources but the remoteness of the Southern Ocean from continents not covered by ice sheets makes the source of REEs to seawater enigmatic. The main source of other continent-derived trace elements such as $\mathrm{Fe}$ is thought to be the Antarctic shelves, from where they are advected horizontally (de Jong et al., 2012). Although we find some evidence for contributions of REEs from a fresh sedimentary source in AABW (section 4.1) the deepwater concentrations are generally uniform and additional sedimentary sources should be reflected by the REE patterns. For example, it was previously demonstrated that continental REE inputs occur in the surface waters near the Cape of Good Hope and the Antarctic Peninsula (Stichel et al., 2012b).

In other regions, such as the Bay of Bengal (e.g. Amakawa et al., 2000; Singh et al., 2012) or the eastern equatorial Atlantic (Rickli et al., 2010), interaction with continent-derived particles can be a large source of REEs to seawater. Hegner et al. (2007) studied the $\mathrm{Nd}$ concentration and isotope composition of particles in the Atlantic sector of the Southern Ocean and found the highest $\mathrm{Nd}$ concentrations in samples with low particle concentrations and low opal content (Hegner et al., 2007). This suggests that these particles are lithogenic but the high REE content of terrigenous particles may not be readily dissolved. The particulate REE data of Garcia-Solsona et al. (2014) indicate that the authigenic fraction (based on ${ }^{232} \mathrm{Th}$ concentration estimates of the lithogenic fraction) generally dominates the REE abundance in the particles from the region. There is evidence for some minor dust input to the region from $\mathrm{Al}$ data but a spike at $55^{\circ} \mathrm{S}$ (Middag et al., 2011b) did not overlap with our sampling stations and little evidence was found in surrounding samples (Stichel et al., 2012b).

Near the Antarctic Peninsula, inputs from shelf and slope sediments in the Admundsen Sea and around King George Island have been observed by more radiogenic Nd isotopic compositions (Carter et al., 2012; Stichel et al., 2012b; Rickli et al., 2014). Although we have very few REE data from that part of the Drake Passage, this input of radiogenic Nd seems to have little effect on the seawater REE patterns (Stichel et al., 2012b) and may be quantitatively unimportant. The continental margin of East Antarctica in the WG has been found not to be a significant source of dissolved Fe (Klunder et al., 2011) or dissolved Mn (Middag et al., 2011a) to the WG. Klunder et al. (2011) hypothesized that this could be related to the low organic carbon content of the sediments that are therefore not reducing enough to mobilise Fe. The 
input of continental material from ice-bergs has also been suggested to be a significant source although this would be very patchy and the supply would likely follow the WG circulation pathways (Hegner et al., 2007). However, no evidence of REE release from drifting ice-bergs has been documented in seawater (Stichel et al., 2012b). The lack of inputs from the East Antarctic continental shelf is supported by ${ }^{228} \mathrm{Ra}$ data although the $\mathrm{La} / \mathrm{Yb}$ ratios of some particles indicate input of old crustal material from East Antarctica (Hegner et al., 2007). Furthermore, the less radiogenic $\mathrm{Nd}$ isotopic composition of AABW in the eastern part of the WG compared to that of LCDW at least suggests exchange with old continental rocks from the East Antarctic shelf (Stichel et al., 2012a). Our dissolved REE data show the highest HREE/LREE ratios (here $(\mathrm{Tm}+\mathrm{Yb}+\mathrm{Lu}) /(\mathrm{La}+\mathrm{Pr}+\mathrm{Nd})$ all PAAS normalised so the average continental source would have values around 1) at stations 104 and 241 far away from East Antarctica. Fluxes from reducing sediments (Haley et al., 2004), sedimentary organic matter (Freslon et al., 2014) and continental input from some large rivers (e.g. Amakawa et al., 2000) can potentially produce a MREE enrichment in seawater. This enrichment or MREE bulge can be quantified by MREE/MREE* (here $(\mathrm{Gd}+\mathrm{Ty}+\mathrm{Db}) /[(\mathrm{Tm}+\mathrm{Yb}+\mathrm{Lu}+\mathrm{La}+\mathrm{Pr}+\mathrm{Nd}) / 2]$ all shale normalised $)$ with pore water samples having values $>1$ (Haley et al., 2004). Consequently the plot of HREE/LREE against MREE/MREE* (Figure 9) demonstrates that continental sources to the Atlantic Sector of the Southern Ocean have not occurred recently, and instead the typical seawater fractionation causes HREE/LREE to be high. The Y/Ho ratios plotted against the Ce anomalies (Figure 9) are opposite in sign (being <1 or >1) compared to those of hydrogenetic Fe-Mn nodules and crusts (Bau et al., 1996, 2014) suggesting that removal onto Fe-Mn oxides may be responsible for these ratios. The actual range of the seawater $\mathrm{Y} / \mathrm{Ho}$ ratios is small with some sites plotting in tight clusters. Taken together, these data suggests that the REEs in the Southern Ocean have been isolated from fresh continental sources for a relatively long time and the high REE concentrations have accumulated over the journey of water masses contributing to CDW around the abyssal oceans.

Chen et al. (2013a) compiled global seawater $\mathrm{Nd}$ concentration data and compared these with ${ }^{228}$ Ra activity data as an indicator for coastal supply. They found that the relationship was not simple and that in some regions, most notably the Southern Ocean, the ${ }^{228}$ Ra activity was low but the surface water Nd was nevertheless high. These authors suggested that globally the vertical flux of $\mathrm{Nd}$ from the subsurface to 
the surface waters is a very important control and our data and $\mathrm{Nd}$ isotope compositions (Stichel et al., 2012a) for the WG certainly support this.

\subsection{Comparison with other trace metals from GEOTRACES studies}

The great advantage of the GEOTRACES program is the possibility to directly compare data for many trace elements and their isotopes obtained on the same samples. For those stations from which we analysed our samples for REE concentrations, analyses of $\mathrm{Al}, \mathrm{Ba}, \mathrm{Mn}, \mathrm{Fe}$, and $\mathrm{Zn}$ concentrations are also available. To compare the data for the different metals a correlation matrix was constructed after extracting the data from the GEOTRACES 2014 intermediate data product (http://www.bodc.ac.uk/geotraces/data/idp2014/). In some instances the ultra-clean rosette and the normal rosette (used to sample for the REEs) did not sample exactly the same water depths. In these cases we have compared samples that were taken within $50 \mathrm{~m}$ water depth from each other. The REEs correlate very well with $\mathrm{Ba}\left(R^{2}\right.$ values from 0.86 for $\mathrm{Sm}$ to 0.96 for $\mathrm{Lu}$ and 0.97 for $\mathrm{Y}$ ) and reasonably well with $\mathrm{Zn}$ $\left(R^{2}\right.$ values from 0.71 for $\mathrm{Eu}$ to 0.88 for $\mathrm{Lu}$ and 0.72 for $\left.\mathrm{Y}\right)$ and $\mathrm{Cu}\left(R^{2}\right.$ values from 0.78 for Eu to 0.85 for $\mathrm{La}$ and 0.69 for $\mathrm{Y}$ ). The results of these comparisons are not surprising given the strong correlation of REE concentrations with alkalinity and silicate and that these other trace metals are also associated with these nutrients (e.g. $\mathrm{Zn}$ and silicate: Croot et al., 2011). The strong correlation of La with Ba was also noted by Garcia-Solsona et al. (2014) who hypothesised La anomalies might be related to barite precipitation. The reasons for these correlations will be the subject of future research but we note that in our sample set the correlations with $\mathrm{Ba}$ are similar for $\mathrm{La}$ and $\mathrm{Lu}$.

A notable lack of correlation is found between REEs and dissolved Fe concentrations (Klunder et al., 2011) and dissolved Mn concentrations (Middag et al., 2011). Both dissolved $\mathrm{Fe}$ and $\mathrm{Mn}$ concentrations were elevated in intermediate depths associated with a hydrothermal plume from the Bouvet triple junction and no evidence was found for this in the REE data in accordance with their scavenging immediately at the vent sites (German et al., 1990c). At station 131 there is a surface Fe maximum related to very low productivity at this site (Klunder et al., 2011) and the REE profiles there support the lack of particles. Deep-water Fe concentrations were higher in the eastward limb of the WG compared to the westward part (Klunder et al., 2011) but no significant difference in REE concentrations (apart from Ce) is seen between stations 
131 and 161. The future combination of REE data and patterns with other trace metals and isotope data has the potential to provide new insights into the sources of the metals and their biogeochemical cycling.

\section{Conclusions}

The concentrations of dissolved REEs in the Atlantic sector of the Southern Ocean reflect the balance between strong particle scavenging and vertical supply. The shape of the profiles changes from the classically increasing REE concentrations with depth in the ACC to essentially invariant depth profiles below the surface waters in the WG. This change results from the drastic difference in productivity on either side of the ACC southern boundary and the strong vertical supply of deep waters in the WG. The change in depth patterns is also reflected in dissolved silicate and total alkalinity measured in these samples. The strongest correlations are found between HREE concentrations and alkalinity although more studies of particle dynamics are required to understand the controlling mechanism. Strongly developed Ce anomalies and the typical "seawater like" REE patterns suggest that the deep waters upwelling on shoaling isopycnals in the WG have been isolated from fresh continental REE sources for a relatively long time. This and the generally high REE concentrations found in CDW suggest that the REE inventory of the Atlantic sector of the southern Ocean predominantly originates from deep waters that have travelled the abyssal IndoPacific oceans and are entrained into the CDW.

\section{Author contributions}

EH, TS and MF designed the research and wrote the manuscript. TS collected the samples. BB conducted the analyses as a bachelor research project supervised by EH and MF.

\section{Acknowledgments}

We thank the Polarstern Crew for help collecting the samples and Jutta Heinze for all the clean tubes.

\section{References}

Akagi, T., F.-f. Fu, Y. Hongo, and K. Takahashi (2011), Composition of rare earth elements in settling particles collected in the highly productive North Pacific Ocean and Bering Sea: Implications for siliceous-matter dissolution kinetics and formation of two REE-enriched 
phases, Geochimica et Cosmochimica Acta, 75(17), 4857-4876.

Alibo, D. S., and Y. Nozaki (1999), Rare earth elements in seawater: particle association, shale-normalization, and Ce oxidation, Geochimica et Cosmochimica Acta, 63(3-4), 363-372. Alibo, D. S., and Y. Nozaki (2000), Dissolved rare earth elements in the South China Sea: Geochemical characterization of the water masses, Journal of Geophysical Research: Oceans, 105(C12), 28771-28783.

Alibo, D. S., and Y. Nozaki (2004), Dissolved rare earth elements in the eastern Indian Ocean: chemical tracers of the water masses, Deep Sea Research Part I: Oceanographic Research Papers, 51(4), 559-576.

Amakawa, H., D. S. Alibo, and Y. Nozaki (2000), Nd isotopic composition and REE pattern in the surface waters of the eastern Indian Ocean and its adjacent seas, Geochimica et Cosmochimica Acta, 64(10), 1715-1727.

Bau, M. (1996), Controls on the fractionation of isovalent trace elements in magmatic and aqueous systems: evidence from Y/Ho, $\mathrm{Zr} / \mathrm{Hf}$, and lanthanide tetrad effect, Contrib Mineral Petrol, 123(3), 323-333.

Bau, M., and A. Koschinsky (2006), Hafnium and neodymium isotopes in seawater and in ferromanganese crusts: The element perspective, Earth and Planetary Science Letters, 241(3), 952-961.

Bau, M., and A. Koschinsky (2009), Oxidative scavenging of cerium on hydrous Fe oxide: Evidence from the distribution of rare earth elements and yttrium between Fe oxides and $\mathrm{Mn}$ oxides in hydrogenetic ferromanganese crusts, Geochemical Journal, 43, 37-47.

Bau, M., A. Koschinsky, P. Dulski, and J. R. Hein (1996), Comparison of the partitioning behaviours of yttrium, rare earth elements, and titanium between hydrogenetic marine ferromanganese crusts and seawater, Geochimica et Cosmochimica Acta, 60(10), 1709-1725. Bau, M., K. Schmidt, A. Koschinsky, J. Hein, T. Kuhn, and A. Usui (2014), Discriminating between different genetic types of marine ferro-manganese crusts and nodules based on rare earth elements and yttrium, Chemical Geology, 381(0), 1-9.

Bayon, G., D. Birot, L. Ruffine, J. C. Caprais, E. Ponzevera, C. Bollinger, J. P. Donval, J. L. Charlou, M. Voisset, and S. Grimaud (2011), Evidence for intense REE scavenging at cold seeps from the Niger Delta margin, Earth and Planetary Science Letters, 312, 443-452.

Bertram, C. J., and H. Elderfield (1993), The geochemical balance of the rare earth elements and neodymium isotopes in the oceans, Geochimica et Cosmochimica Acta, 57(9), 19571986.

Byrne, R. H., and K.-H. Kim (1990), Rare earth element scavenging in seawater, Geochimica et Cosmochimica Acta, 54(10), 2645-2656.

Byrne, R. H., and E. R. Sholkovitz (1996), Chapter 158 Marine chemistry and geochemistry of the lanthanides, in Handbook on the Physics and Chemistry of Rare Earths, edited by Karl A. Gschneidner, Jr. and E. LeRoy, pp. 497-593, Elsevier.

Cantrell, K. J., and R. H. Byrne (1987), Rare earth element complexation by carbonate and oxalate ions, Geochimica et Cosmochimica Acta, 51(3), 597-605.

Carmack, E., and T. Foster (1975), On the flow of water out of the Weddell Sea, Deep Sea Research and Oceanographic Abstracts, 22(11), 711-724.

Carter, P., D. Vance, C. D. Hillenbrand, J. A. Smith, and D. R. Shoosmith (2012), The neodymium isotopic composition of waters masses in the eastern Pacific sector of the Southern Ocean, Geochimica et Cosmochimica Acta, 79(0), 41-59.

Chen, T.-Y., J. Rempfer, M. Frank, R. Stumpf, and M. Molina-Kescher (2013a), Upper ocean vertical supply: A neglected primary factor controlling the distribution of neodymium concentrations of open ocean surface waters?, Journal of Geophysical Research: Oceans, 118(8), 3887-3894.

Chen, T.-Y., R. Stumpf, M. Frank, J. Beldowski, and M. Staubwasser (2013b), Contrasting 
geochemical cycling of hafnium and neodymium in the central Baltic Sea, Geochimica et Cosmochimica Acta, 123(0), 166-180.

Croot, P. L., O. Baars, and P. Streu (2011), The distribution of dissolved zinc in the Atlantic sector of the Southern Ocean, Deep Sea Research Part II: Topical Studies in Oceanography, 58(25), 2707-2719.

de Baar, H. J. W., M. P. Bacon, P. G. Brewer, and K. W. Bruland (1985), Rare earth elements in the Pacific and Atlantic Oceans, Geochimica et Cosmochimica Acta, 49(9), 1943-1959. de Jong, J., V. Schoemann, D. Lannuzel, P. Croot, H. de Baar, and J.-L. Tison (2012), Natural iron fertilization of the Atlantic sector of the Southern Ocean by continental shelf sources of the Antarctic Peninsula, Journal of Geophysical Research: Biogeosciences, 117(G1), G01029.

Elderfield, H. (1988), The Oceanic Chemistry of the Rare-Earth Elements, Philosophical Transactions of the Royal Society of London. Series A, Mathematical and Physical Sciences, 325(1583), 105-126.

Elderfield, H., and M. J. Greaves (1982), The rare earth elements in seawater, Nature, 296(5854), 214-219.

Ferrari, R., M. F. Jansen, J. F. Adkins, A. Burke, A. L. Stewart, and A. F. Thompson (2014), Antarctic sea ice control on ocean circulation in present and glacial climates, Proceedings of the National Academy of Sciences, 111(24), 8753-8758.

Frank, M. (2002), Radiogenic isotopes: Tracers of past ocean circulation and weathering inputs, Reviews of Geophysics, 40(1), 1001, 10.1029/2000RG000094.

Freslon, N., et al. (2014), Rare earth elements and neodymium isotopes in sedimentary organic matter, Geochimica et Cosmochimica Acta, 140, 177-198.

Garcia-Solsona, E., C. Jeandel, M. Labatut, F. Lacan, D. Vance, V. Chavagnac, and C. Pradoux (2014), Rare earth elements and Nd isotopes tracing water mass mixing and particleseawater interactions in the SE Atlantic, Geochimica et Cosmochimica Acta, 125(0), 351372.

Geibert, W., M. M. Rutgers van der Loeff, C. Hanfland, and H. J. Dauelsberg (2002), Actinium-227 as a deep-sea tracer: sources, distribution and applications, Earth and Planetary Science Letters, 198(1), 147-165.

German, C. R., and H. Elderfield (1990a), Rare earth elements in the NW Indian Ocean, Geochimica et Cosmochimica Acta, 54(7), 1929-1940.

German, C. R., and H. Elderfield (1990b), Application of the Ce anomaly as a paleoredox indicator: The ground rules, Paleoceanography, 5, 823-833.

German, C. R., G. P. Klinkhammer, J. M. Edmond, A. Mitra, and H. Elderfield (1990c), Hydrothermal scavenging of rare earth elements in the ocean, Nature, 345, 516-518.

German, C. R., T. Masuzawa, M. J. Greaves, H. Elderfield, and J. M. Edmond (1995), Dissolved rare earth elements in the Southern Ocean: Cerium oxidation and the influence of hydrography, Geochimica et Cosmochimica Acta, 59(8), 1551-1558.

Gordon, A. L. (1971), Oceanography of Antarctic waters, edited by J. L. Reid, pp. 169-203. Goswami, V., S. K. Singh, and R. Bhushan (2014), Impact of water mass mixing and dust deposition on Nd concentration and eNd of the Arabian Sea water column, Geochimica et Cosmochimica Acta, 145(0), 30-49.

Grasse, P., T. Stichel, R. Stumpf, L. Stramma, and M. Frank (2012), The distribution of neodymium isotopes and concentrations in the Eastern Equatorial Pacific: Water mass advection versus particle exchange, Earth and Planetary Science Letters, 353, 198-207. Grenier, M., C. Jeandel, F. Lacan, D. Vance, C. Venchiarutti, A. Cros, and S. Cravatte (2013), From the subtropics to the central equatorial Pacific Ocean: Neodymium isotopic composition and rare earth element concentration variations, Journal of Geophysical Research: Oceans, 118(2), 592-618. 
Haley, B. A., M. Frank, E. Hathorne, and N. Pisias (2014), Biogeochemical implications from dissolved rare earth element and $\mathrm{Nd}$ isotope distributions in the Gulf of Alaska, Geochimica et Cosmochimica Acta, 126(0), 455-474.

Haley, B. A., G. P. Klinkhammer, and J. McManus (2004), Rare earth elements in pore waters of marine sediments, Geochimica et Cosmochimica Acta, 68(6), 1265-1279.

Hara, Y., H. Obata, T. Doi, Y. Hongo, T. Gamo, S. Takeda, and A. Tsuda (2009), Rare earth elements in seawater during an iron-induced phytoplankton bloom of the western subarctic Pacific (SEEDS-II), Deep Sea Research Part II: Topical Studies in Oceanography, 56(26), 2839-2851.

Hathorne, E. C., B. Haley, T. Stichel, P. Grasse, M. Zieringer, and M. Frank (2012), Online preconcentration ICP-MS analysis of rare earth elements in seawater, Geochemistry, Geophysics, Geosystems, 13(1), Q01020.

Hatje, V., K. W. Bruland, and A. R. Flegal (2014), Determination of rare earth elements after pre-concentration using NOBIAS-chelate PA-1 resin: Method development and application in the San Francisco Bay plume, Marine Chemistry, 160(0), 34-41.

Hegner, E., H. J. Dauelsberg, M. M. Rutgers van der Loeff, C. Jeandel, and H. J. W. de Baar (2007), Nd isotopic constraints on the origin of suspended particles in the Atlantic Sector of the Southern Ocean, Geochemistry, Geophysics, Geosystems, 8(10), Q10008.

Heywood, K. J., and B. A. King (2002), Water masses and baroclinic transports in the South Atlantic and Southern oceans, Journal of Marine Research, 60(5), 639-676.

Hongo, Y., H. Obata, D. Sotto Alibo, and Y. Nozaki (2006), Spatial variations of rare earth elements in north pacific surface water, J Oceanogr, 62(4), 441-455.

Hoppema, M., E. Fahrbach, M. H. C. Stoll, and H. J. W. de Baar (1999), Annual uptake of atmospheric $\mathrm{CO} 2$ by the Weddell Sea derived from a surface layer balance, including estimations of entrainment and new production, Journal of Marine Systems, 19(4), 219-233. Ito, T., P. Parekh, S. Dutkiewicz, and M. J. Follows (2005), The Antarctic Circumpolar Productivity Belt, Geophysical Research Letters, 32(13), L13604.

Jeandel, C. (1993), Concentration and isotopic composition of $\mathrm{Nd}$ in the South Atlantic Ocean, Earth and Planetary Science Letters, 117, 581-591.

Jeandel, C., J. K. Bishop, and A. Zindler (1995), Exchange of neodymium and its isotopes between seawater and small and large particles in the Sargasso Sea, Geochimica et Cosmochimica Acta, 59(3), 535-547.

Klatt, O., E. Fahrbach, M. Hoppema, and G. Rohardt (2005), The transport of the Weddell Gyre across the Prime Meridian, Deep Sea Research Part II: Topical Studies in Oceanography, 52(3-4), 513-528.

Klunder, M. B., P. Laan, R. Middag, H. J. W. De Baar, and J. C. van Ooijen (2011), Dissolved iron in the Southern Ocean (Atlantic sector), Deep Sea Research Part II: Topical Studies in Oceanography, 58, 2678-2694.

Lacan, F., K. Tachikawa, and C. Jeandel (2012), Neodymium isotopic composition of the oceans: A compilation of seawater data, Chemical Geology, 300, 177-184.

Le Moigne, F. A. C., M. Boye, A. Masson, R. Corvaisier, E. Grossteffan, A. Guéneugues, and P. Pondaven (2013), Description of the biogeochemical features of the subtropical southeastern Atlantic and the Southern Ocean south of South Africa during the austral summer of the International Polar Year, Biogeosciences, 10(1), 281-295.

Marinov, I., A. Gnanadesikan, J. R. Toggweiler, and J. L. Sarmiento (2006), The Southern Ocean biogeochemical divide, Nature, 441(7096), 964-967.

Martinez-Garcia, A., D. M. Sigman, H. Ren, R. F. Anderson, M. Straub, D. A. Hodell, S. L. Jaccard, T. I. Eglinton, and G. H. Haug (2014), Iron Fertilization of the Subantarctic Ocean During the Last Ice Age, Science, 343(6177), 1347-1350.

Key, R. M., A. Kozyr, C. L. Sabine, K. Lee, R. Wanninkhof, J. L. Bullister, R. A. Feely, F. J. 
Millero, C. Mordy, and T.-H. Peng (2004), A global ocean carbon climatology: Results from Global Data Analysis Project (GLODAP), Global Biogeochem. Cycles, 18, GB4031, doi:10.1029/2004GB002247.

Meijers, A. J. S., A. Klocker, N. L. Bindoff, G. D. Williams, and S. J. Marsland (2010), The circulation and water masses of the Antarctic shelf and continental slope between 30 and 80E, Deep Sea Research Part II: Topical Studies in Oceanography, 57(9-10), 723-737. Middag, R., H. J. W. de Baar, P. Laan, P. H. Cai, and J. C. van Ooijen (2011a), Dissolved manganese in the Atlantic sector of the Southern Ocean, Deep Sea Research Part II: Topical Studies in Oceanography, 58, 2661-2677.

Middag, R., C. van Slooten, H. J. W. de Baar, and P. Laan (2011b), Dissolved aluminium in the Southern Ocean, Deep Sea Research Part II: Topical Studies in Oceanography, 58, 26472660.

Moffett, J. M. (1990), Microbially mediated cerium oxidation in sea water, Nature, 345, 421423.

Molina-Kescher, M., M. Frank, and E. Hathorne (2014), South Pacific dissolved Nd isotope compositions and rare earth element distributions: Water mass mixing versus biogeochemical cycling, Geochimica et Cosmochimica Acta, 127(0), 171-189.

Nozaki, Y., D.-S. Alibo, H. Amakawa, T. Gamo, and H. Hasumoto (1999), Dissolved rare earth elements and hydrography in the Sulu Sea, Geochimica et Cosmochimica Acta, 63(15), 2171-2181.

Nozaki, Y., and D. S. Alibo (2003a), Importance of vertical geochemical processes in controlling the oceanic profiles of dissolved rare earth elements in the northeastern Indian Ocean, Earth and Planetary Science Letters, 205(3-4), 155-172.

Nozaki, Y., and D. S. Alibo (2003b), Dissolved rare earth elements in the Southern Ocean, southwest of Australia: Unique patterns compared to the South Atlantic data, Geochemical Journal, 37, 47-62.

Oka, A., H. Hasumi, H. Obata, T. Gamo, and Y. Yamanaka (2009), Study on vertical profiles of rare earth elements by using an ocean general circulation model, Global Biogeochemical Cycles, 23(4), GB4025.

Orsi, A. H., W. M. Smethie Jr, and J. L. Bullister (2002), On the total input of Antarctic waters to the deep ocean: A preliminary estimate from chlorofluorocarbon measurements, Journal of Geophysical Research, 107(C8), 3122-3122.

Orsi, A. H., T. Whitworth Iii, and W. D. Nowlin Jr (1995), On the meridional extent and fronts of the Antarctic Circumpolar Current, Deep Sea Research Part I: Oceanographic Research Papers, 42(5), 641-673.

Osborne, A. H., B. A. Haley, E. C. Hathorne, S. Flögel, and M. Frank (2014), Neodymium isotopes and concentrations in Caribbean seawater: Tracing water mass mixing and continental input in a semi-enclosed ocean basin, Earth and Planetary Science Letters, 406(0), 174-186.

Pahnke, K., T. van de Flierdt, K. M. Jones, M. Lambelet, S. R. Hemming, and S. L. Goldstein (2012), GEOTRACES intercalibration of neodymium isotopes and rare earth element concentrations in seawater and suspended particles. Part 2: Systematic tests and baseline profiles, Limnology and Oceanography: Methods, 10, 252-269.

Pena, L. D., and S. L. Goldstein (2014), Thermohaline circulation crisis and impacts during the mid-Pleistocene transition, Science, 345(6194), 318-322.

Piepgras, D. J., and S. B. Jacobsen (1992), The behavior of rare earth elements in seawater: Precise determination of variations in the North Pacific water column, Geochimica et Cosmochimica Acta, 56(5), 1851-1862.

Piepgras, D. J., and G. J. Wasserburg (1980), Neodymium isotopic variations in seawater, Earth and Planetary Science Letters, 50(1), 128-138. 
Pierrot, D., E. Lewis, and D. W. R. Wallace (2006), MS Excel Program Developed for CO2 System Calculations, Carbon Dioxide Information Analysis Center,

Oak Ridge National Laboratory.

Piotrowski, A. M., S. L. Goldstein, S. R. Hemming, and R. G. Fairbanks (2005), Temporal Relationships of Carbon Cycling and Ocean Circulation at Glacial Boundaries, Science, 307(5717), 1933-1938.

Raymond, K. N., D. L. Wellman, C. Sgarlata, and A. P. Hill (2010), Curvature of the lanthanide contraction: An explanation, Comptes Rendus Chimie, 13, 849-852.

Reid, J., and R. Lynn (1971), On the influence of the Norwegian-Greenland and Weddell seas upon the bottom waters of the Indian and Pacific oceans, Deep-Sea Research, 18(11), 10631088.

Rempfer, J., T. F. Stocker, F. Joos, and J.-C. Dutay (2012), Sensitivity of Nd isotopic composition in seawater to changes in $\mathrm{Nd}$ sources and paleoceanographic implications, Journal of Geophysical Research: Oceans, 117(C12), C12010.

Rickli, J., M. Frank, A. R. Baker, S. Aciego, G. de Souza, R. B. Georg, and A. N. Halliday (2010), Hafnium and neodymium isotopes in surface waters of the eastern Atlantic Ocean: Implications for sources and inputs of trace metals to the ocean, Geochimica et Cosmochimica Acta, 74(2), 540-557.

Rickli, J., M. Gutjahr, D. Vance, M. Fischer-Gödde, C.-D. Hillenbrand, and G. Kuhn (2014), Neodymium and hafnium boundary contributions to seawater along the West Antarctic continental margin, Earth and Planetary Science Letters, 394, 99-110.

Roeske, T., and M. M. Rutgers van der Loeff (2014), GEOTRACES Intermediate Data Product.

Rousseau, T. C. C., J. E. Sonke, J. Chmeleff, F. Candaudap, F. Lacan, G. Boaventura, P. Seyler, and C. Jeandel (2013), Rare earth element analysis in natural waters by multiple isotope dilution - sector field ICP-MS, Journal of Analytical Atomic Spectrometry, 28(4), 573-584.

Rutgers van der Loeff, M., P. H. Cai, I. Stimac, A. Bracher, R. Middag, M. B. Klunder, and S. M. A. C. van Heuven (2011), ${ }^{234}$ Th in surface waters: Distribution of particle export flux across the Antarctic Circumpolar Current and in the Weddell Sea during the GEOTRACES expedition ZERO and DRAKE, Deep Sea Research Part II: Topical Studies in Oceanography, 58, 2749-2766.

Schijf, J., H. J. W. De Baar, and F. J. Millero (1995), Vertical distributions and speciation of dissolved rare earth elements in the anoxic brines of Bannock Basin, eastern Mediterranean Sea, Geochimica et Cosmochimica Acta, 59(16), 3285-3299.

Schijf, J., and A. M. Zoll (2011), When dissolved is not truly dissolved: The importance of colloids in studies of metal sorption on organic matter, Journal of Colloid and Interface Science, 361(1), 137-147.

Schmitz, W. J. (1995), On the interbasin-scale thermohaline circulation, Reviews of Geophysics, 33(2), 151-173.

Shannon, R. D. (1976), Revised effective ionic radii and systematic studies of interatomic distances in halides and chalcogenides, Acta Crystallographica Section A, 32(5), 751-767. Shimizu, H., K. Tachikawa, A. Masuda, and Y. Nozaki (1994), Cerium and neodymium isotope ratios and REE patterns in seawater from the North Pacific Ocean, Geochimica et Cosmochimica Acta, 58(1), 323-333.

Sholkovitz, E. R., W. M. Landing, and B. L. Lewis (1994), Ocean particle chemistry: The fractionation of rare earth elements between suspended particles and seawater, Geochimica et Cosmochimica Acta, 58(6), 1567-1579.

Sholkovitz, E. R., and D. L. Schneider (1991), Cerium redox cycles and rare earth elements in the Sargasso Sea, Geochimica et Cosmochimica Acta, 55(10), 2737-2743. 
Sigman, D. M., M. P. Hain, and G. H. Haug (2010), The polar ocean and glacial cycles in atmospheric CO2 concentration, Nature, 466(7302), 47-55.

Singh, S. P., S. K. Singh, V. Goswami, R. Bhushan, and V. K. Rai (2012), Spatial distribution of dissolved neodymium and eNd in the Bay of Bengal: Role of particulate matter and mixing of water masses, Geochimica et Cosmochimica Acta, 94(0), 38-56. Stichel, T., M. Frank, J. Rickli, and B. A. Haley (2012a), The hafnium and neodymium isotope composition of seawater in the Atlantic sector of the Southern Ocean, Earth and Planetary Science Letters, 317, 282-294.

Stichel, T., M. Frank, J. Rickli, E. C. Hathorne, B. A. Haley, C. Jeandel, and C. Pradoux (2012b), Sources and input mechanisms of hafnium and neodymium in surface waters of the Atlantic sector of the Southern Ocean, Geochimica et Cosmochimica Acta, 94, 22-37.

Stramma, L., and M. England (1999), On the water masses and mean circulation of the South Atlantic Ocean, Journal of Geophysical Research, 104(C9), 20863-20883.

Tachikawa, K., C. Jeandel, A. Vangriesheim, and B. Dupré (1999), Distribution of rare earth elements and neodymium isotopes in suspended particles of the tropical Atlantic Ocean (EUMELI site), Deep Sea Research Part I: Oceanographic Research Papers, 46(5), 733-755. Taylor, S. R., and S. M. McLennan (1985), The continental crust, its composition and evolution: An examination of the geochemical record preserved in sedimentary rocks, Blackwell Scientific, Oxford.

Thompson, A., M. K. Amistadi, O. A. Chadwick, and J. Chorover (2013), Fractionation of yttrium and holmium during basaltic soil weathering, Geochimica et Cosmochimica Acta, $119,18-30$.

Thuróczy, C. E., L. J. A. Gerringa, M. B. Klunder, P. Laan, and H. J. W. de Baar (2011), Observation of consistent trends in the organic complexation of dissolved iron in the Atlantic sector of the Southern Ocean, Deep Sea Research Part II: Topical Studies in Oceanography, 58, 2695-2706.

Usbeck, R., M. Rutgers van der Loeff, M. Hoppema, and R. Schlitzer (2002), Shallow remineralization in the Weddell Gyre, Geochemistry, Geophysics, Geosystems, 3(1), 1-18. van de Flierdt, T., et al. (2012), GEOTRACES intercalibration of neodymium isotopes and rare earth element concentrations in seawater and suspended particles. Part 1: reproducibility of results for the international intercomparison, Limnology and Oceanography: Methods, 10, 234-251.

van Heuven, S. M. A. C., M. Hoppema, O. Huhn, H. A. Slagter, and H. J. W. de Baar (2011), Direct observation of increasing CO2 in the Weddell Gyre along the Prime Meridian during 1973-2008, Deep Sea Research Part II: Topical Studies in Oceanography, 58, 2613-2635. Wang, Z.-L., and M. Yamada (2007), Geochemistry of dissolved rare earth elements in the Equatorial Pacific Ocean, Environ Geol, 52(4), 779-787.

Whitworth III, T., and W. D. Nowlin (1987), Water Masses and Currents of the Southern Ocean at the Greenwich Meridian, Journal of Geophysical Research, 92(7), 6462-6476.

Wilson, D. J., A. M. Piotrowski, A. Galy, and J. A. Clegg (2013), Reactivity of neodymium carriers in deep sea sediments: Implications for boundary exchange and paleoceanography, Geochimica et Cosmochimica Acta, 109(0), 197-221.

Zhang, J., and Y. Nozaki (1996), Rare earth elements and yttrium in seawater: ICP-MS determinations in the East Caroline, Coral Sea, and South Fiji basins of the western South Pacific Ocean, Geochimica et Cosmochimica Acta, 60(23), 4631-4644.

Zhang, J., and Y. Nozaki (1998), Behavior of rare earth elements in seawater at the ocean margin: a study along the slopes of the Sagami and Nankai troughs near Japan, Geochimica et Cosmochimica Acta, 62(8), 1307-1317.

Zhang, Y., F. Lacan, and C. Jeandel (2008), Dissolved rare earth elements tracing lithogenic inputs over the Kerguelen Plateau (Southern Ocean), Deep Sea Research Part II: Topical 
Studies in Oceanography, 55, 638-652.

Zheng, X.-Y., J. Yang, and G. M. Henderson (2014), A Robust Procedure for High-Precision Determination of Rare Earth Element Concentrations in Seawater, Geostandards and Geoanalytical Research, doi: 10.1111/j.1751-908X.2014.00307.x.

\section{Figure Captions}

Figure 1. Map showing the location of stations analysed in this study (red dots) and near surface samples presented in Stichel et al. (2012b) (black dots). Grey arrows indicate the main currents in the study area: the South Atlantic Current (SAC), the Antarctic Circumpolar Current (ACC) and the Weddell Gyre (WG). The approximate positions of the following fronts are also marked after Orsi et al. (1995): Sub-Tropical Front (STF), Sub-Antarctic Front (SAF), Polar Front (PF), southern ACC Front (SACCF), and the southern boundary of the ACC (BDY).

Figure 2. Selected rare earth element concentrations for all depth profiles from this study. Error bars represent the $2 \sigma$ uncertainty estimated by repeated measurement (n $=6$ ) of the BATS $15 \mathrm{~m}$ reference seawater during the course of this study (Table 1).

Figure 3. Alkalinity profiles for all investigated stations (St. 101 to St. 241) and dissolved silicate for zero meridian stations (St. 101 to St. 161) from GIPY5:

ANTXXIV/3 (van Heuven et al., 2011) and stations S2, S3, S4, and \#77 from GIPY4: MD166 (Garcia-Solsona et al. 2014) for which the silicate data were published in Le Moigne et al. (2013). Inserts show the correlation of Lu with alkalinity and silicate. This is also shown in supplementary figure 2 .

Figure 4 (a) (b). Rare earth element concentrations for the three crossover stations between GEOTRACES GIPY4 (Garcia-Solsona et al., 2014 denoted by G-S '14) and GIPY5 (PS71) cruises (this study). Only six representative elements are shown here; the remaining elements are shown in supplementary figure 1. Error bars for stations 101 and 104 represent the $2 \sigma$ uncertainty estimated by repeated measurement $(n=6)$ of the BATS $15 \mathrm{~m}$ reference seawater during the course of this study (Table 1). Error bars for station 113 (also $2 \sigma$ ) were estimated by the repeated measurement of the $1000 \mathrm{~m}$ sample (Table 1) using time resolved data collection.

Figure 5. Post Archean Australian Sedimentary (PAAS) rock composite (Taylor and McLennan, 1985) normalised rare earth element patterns for representative stations.

Figure 6(a). Seawater REE patterns normalised to an average LCDW (Table 1). Considering the analytical uncertainties, any points within the grey bar can be considered identical to LCDW. Note the different scaling of the y-axis between ACC (left panel) and WG (right panel).

Figure 6(b). Seawater REE patterns normalised to an average LCDW (Table 1). Considering the analytical uncertainties, any points within the grey bar can be considered identical to LCDW. Note the different scaling of the $y$-axis between ACC (left panel) and WG (right panel).

Figure 7. The latitudinal variation of the increase of Nd concentrations with depth $\Delta[\mathrm{Nd}]$ and the steady state ${ }^{234} \mathrm{Th}$ flux from Rutgers van der Loeff et al (2011) along 
the zero meridian transect. The position of the different fronts are also marked according to Rutgers van der Loeff et al (2011).

Figure 8. The Ce anomaly (calculated relative to Pr and Nd) of all stations. Error bars represent the $2 \sigma$ uncertainty estimated by repeated measurement $(n=6)$ of the BATS $15 \mathrm{~m}$ reference seawater during the course of this study.

Figure 9. Rare earth element pattern indices (all PAAS (Taylor and McLennan, 1985) normalised); (left) middle REE bulge index versus the HREE to LREE ratio, (right) cerium anomaly against the yttrium to holmium ratio. Error bars, only plotted for one station for clarity, represent the $2 \sigma$ uncertainty estimated by repeated measurement ( $\mathrm{n}$ $=6$ ) of the BATS $15 \mathrm{~m}$ reference seawater during the course of this study. This is actually larger than the values for St. 113 that was measured with time resolved data collection but is representative for all samples. 


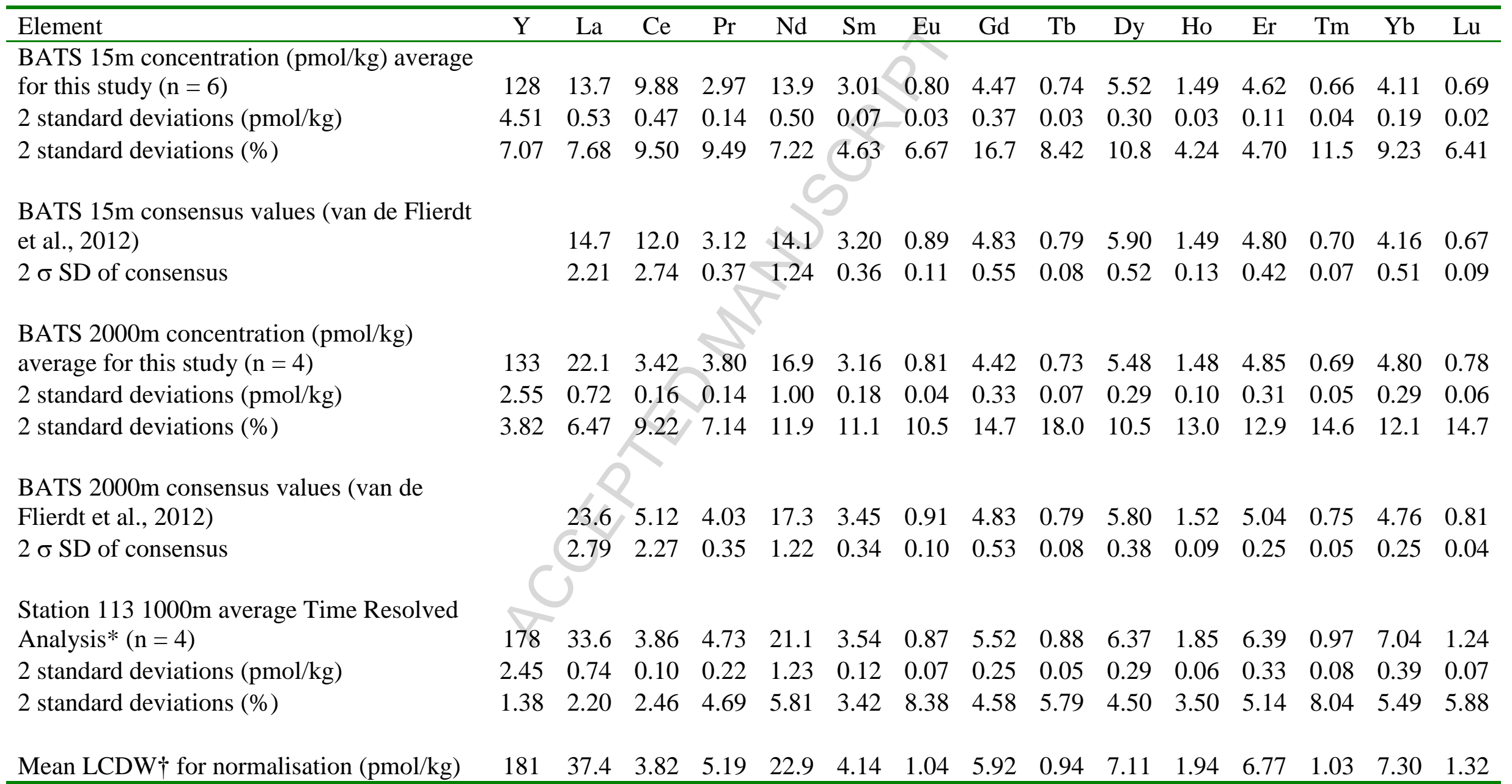

Table 1. REE concentrations in reference samples measured in the course of this study. *Time Resolved Analysis enables the elution peak to be sampled at the highest frequency improving the precision of the measurements. $†$ LCDW composition is the average of St. $131400 \mathrm{~m}, 1000 \mathrm{~m}$ and 
St. 113, 1000m for all elements and also station S4, 1117m, 1680m and S5, 692m, 1185m and 1776m from Garcia-Solsona et al. (2014) for La Lu.

\begin{tabular}{|c|c|c|c|c|c|c|c|c|c|c|}
\hline Reference & Ocean Basin & $\begin{array}{c}\text { Statio } \\
\mathrm{n}\end{array}$ & $\begin{array}{c}\text { Water } \\
\text { depth }(\mathrm{m})\end{array}$ & $\begin{array}{c}\mathrm{La} \\
(\mathrm{pmol} / \mathrm{kg} \\
)\end{array}$ & $\begin{array}{c}\mathrm{Ce} \\
(\mathrm{pmol} / \mathrm{kg})\end{array}$ & $\begin{array}{c}\mathrm{Pr} \\
(\mathrm{pmol} / \\
\mathrm{kg})\end{array}$ & $\begin{array}{c}\mathrm{Nd} \\
(\mathrm{pmol} / \mathrm{kg})\end{array}$ & $\begin{array}{l}\mathrm{Ce} / \mathrm{Ce}^{*} \\
(\mathrm{Pr}+\mathrm{Nd})\end{array}$ & $\begin{array}{c}\mathrm{Ce} / \mathrm{Ce}^{*} \\
(\mathrm{La}+\mathrm{Pr})\end{array}$ & $\begin{array}{l}\mathrm{Ce} / \mathrm{Ce}^{*} \\
(\mathrm{La}+\mathrm{Nd})\end{array}$ \\
\hline This study & $\begin{array}{l}\text { Southern Ocean Drake } \\
\text { Passage } \\
\text { Southern Ocean Atlantic }\end{array}$ & $\begin{array}{l}\text { Station } \\
241 \\
\text { Station }\end{array}$ & 2800 & 32.48 & 2.18 & 4.54 & 19.54 & 0.06 & 0.04 & 0.04 \\
\hline $\begin{array}{l}\text { This study }(\mathrm{n}=4) \\
\text { Zhang \& Nozaki }\end{array}$ & sector LCDW & 113 & 1000 & 33.64 & 3.86 & 4.73 & 21.15 & 0.13 & 0.07 & 0.06 \\
\hline 1996 & W equatorial Pacific & SA-5 & 5149 & 43.04 & 1.99 & 6.42 & 27.92 & 0.04 & 0.03 & 0.02 \\
\hline $\begin{array}{l}\text { Grenier et al. } 2013 \\
\text { Zhang \& Nozaki }\end{array}$ & W equatorial Pacific & EUC 14 & 4000 & 46.38 & 2.47 & 6.27 & 28.08 & 0.05 & 0.03 & 0.03 \\
\hline 1996 & SW Pacific & SA-12 & 4519 & 37.80 & 2.34 & 5.18 & 22.86 & 0.06 & 0.04 & 0.03 \\
\hline $\begin{array}{l}\text { Nozaki \& Alibo } \\
2003 \\
\text { Piepgras \& }\end{array}$ & $\begin{array}{l}\text { Southern Ocean Indian } \\
\text { sector }\end{array}$ & PA4 & 4630 & 16.4 & 2.15 & 4.41 & 20.8 & 0.07 & 0.06 & 0.06 \\
\hline $\begin{array}{l}\text { Jacobsen } 1992 \\
\text { Bertram \& }\end{array}$ & tropical NW Pacific & & 5073 & 52.70 & 5.68 & & 35.00 & & & 0.06 \\
\hline Elderfield 1993 & N Madagascar Basin & & 4251 & 47.47 & 5.06 & & 28.32 & & & 0.06 \\
\hline $\begin{array}{l}\text { Haley et al. } 2014 \\
\text { Bertram \& }\end{array}$ & Gulf of Alaska NE Pacific & & 5000 & 63.60 & 7.40 & 9.89 & 42.53 & 0.10 & 0.07 & 0.06 \\
\hline $\begin{array}{l}\text { Elderfield } 1993 \\
\text { Bertram \& }\end{array}$ & N Mascarene Basin & & 4499 & 43.35 & 5.21 & & 28.30 & & & 0.06 \\
\hline $\begin{array}{l}\text { Elderfield } 1993 \\
\text { Piepgras \& }\end{array}$ & S Somali Basin & & 4845 & 45.22 & 5.57 & & 29.56 & & & 0.06 \\
\hline Jacobsen 1992 & NW Pacific & & 5408 & 61.60 & 8.44 & & 44.40 & & & 0.07 \\
\hline $\begin{array}{l}\text { Nozaki et al. } 1999 \\
\text { Molina-Kescher et }\end{array}$ & Sulu Sea & & 4944 & 26.90 & 4.03 & 4.96 & 23.60 & 0.12 & 0.08 & 0.07 \\
\hline al. $2014^{*}$ & SW Pacific & St. 66 & 5155 & 41.70 & 6.53 & 6.47 & 29.50 & 0.14 & 0.09 & 0.08 \\
\hline
\end{tabular}




\begin{tabular}{|c|c|c|c|c|c|c|c|c|c|c|}
\hline $\begin{array}{l}\text { Wang \& Yamada } \\
2007\end{array}$ & equatorial Pacific & St 12 & 5378 & 31.24 & 5.36 & 4.93 & 21.06 & 0.14 & 0.10 & 0.09 \\
\hline $\begin{array}{l}\text { Pahnke et al. } 2012 \\
\text { Wang \& Yamada }\end{array}$ & Sargasso Sea N Atlantic & BATS & 4500 & 37.72 & 6.78 & 6.53 & 27.66 & 0.13 & 0.10 & 0.09 \\
\hline $\begin{array}{l}2007 \\
\text { German \& }\end{array}$ & equatorial Pacific & St 14 & 5105 & 32.88 & 5.70 & 4.85 & 20.60 & 0.15 & 0.10 & 0.09 \\
\hline $\begin{array}{l}\text { Elderfield } 1990 \\
\text { Molina-Kescher et }\end{array}$ & Arabian Sea & St 1605 & 2500 & 31.20 & 5.40 & & 19.20 & & & 0.09 \\
\hline $\begin{array}{l}\text { al 2014* } \\
\text { Zhang \& Nozaki }\end{array}$ & Chile Basin SE Pacific & St. 22 & 4142 & 33.80 & 7.74 & 4.68 & 21.00 & 0.23 & 0.14 & 0.12 \\
\hline $\begin{array}{l}1996 \\
\text { Elderfield \& }\end{array}$ & Coral Sea & SA-7 & 4562 & 35.86 & 9.49 & 5.47 & 23.85 & 0.23 & 0.15 & 0.14 \\
\hline Greaves 1982 & N Atlantic MOW & & 900 & 20.80 & 9.64 & & 21.10 & & & 0.21 \\
\hline Shimizu et al. 1994 & N Pacific & DE4 & 5200 & 22.70 & 14.80 & & 30.10 & & & 0.27 \\
\hline
\end{tabular}

Table 2. Cerium anomalies from the literature. All REE concentrations were normalised to PAAS before the Ce/Ce* was calculated. *The $\mathrm{Ce} / \mathrm{Ce}^{*}$ values given in Molina-Kescher et al., 2014 were calculated incorrectly and correct values are presented here. 


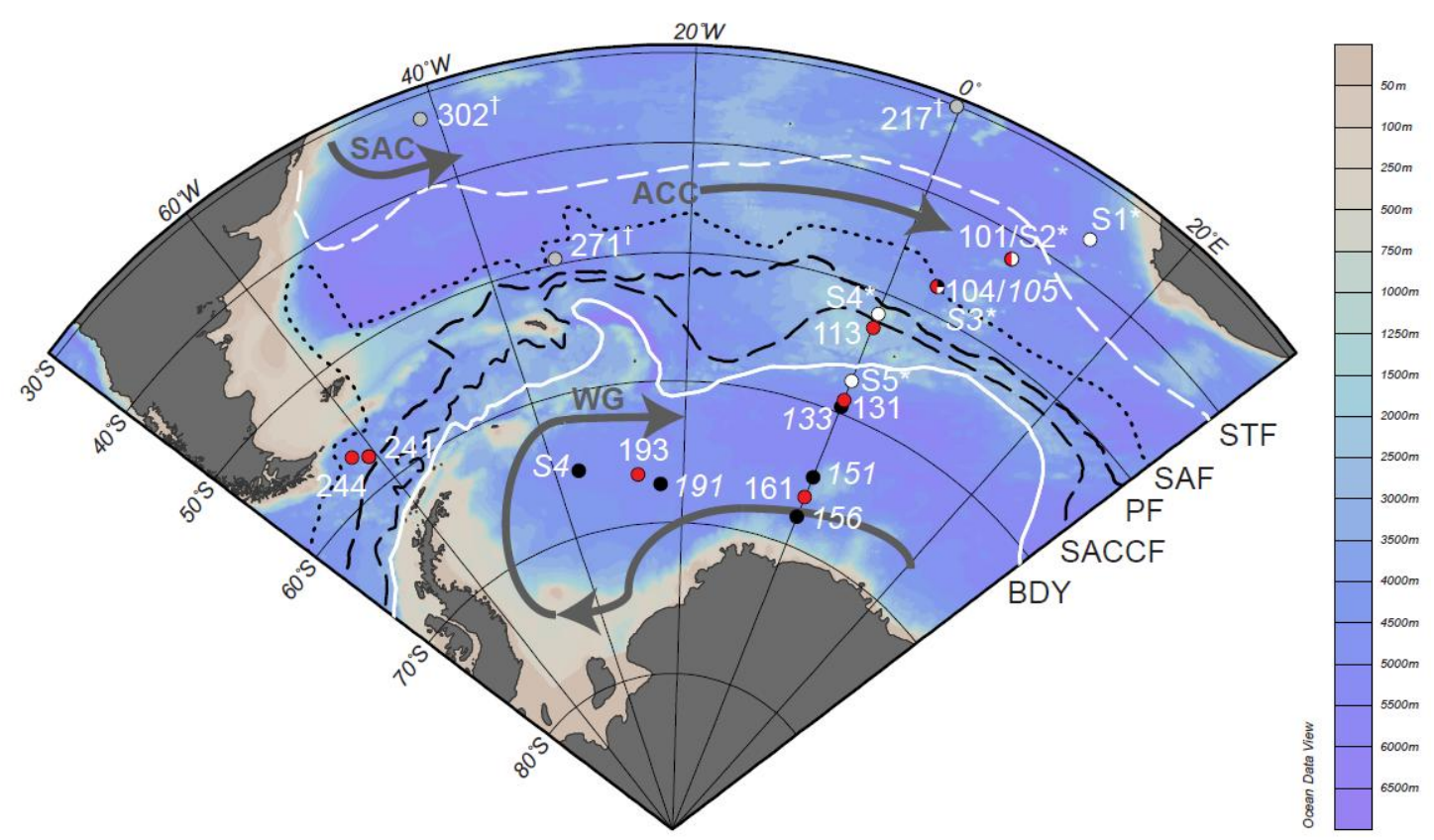

Fig. 1 

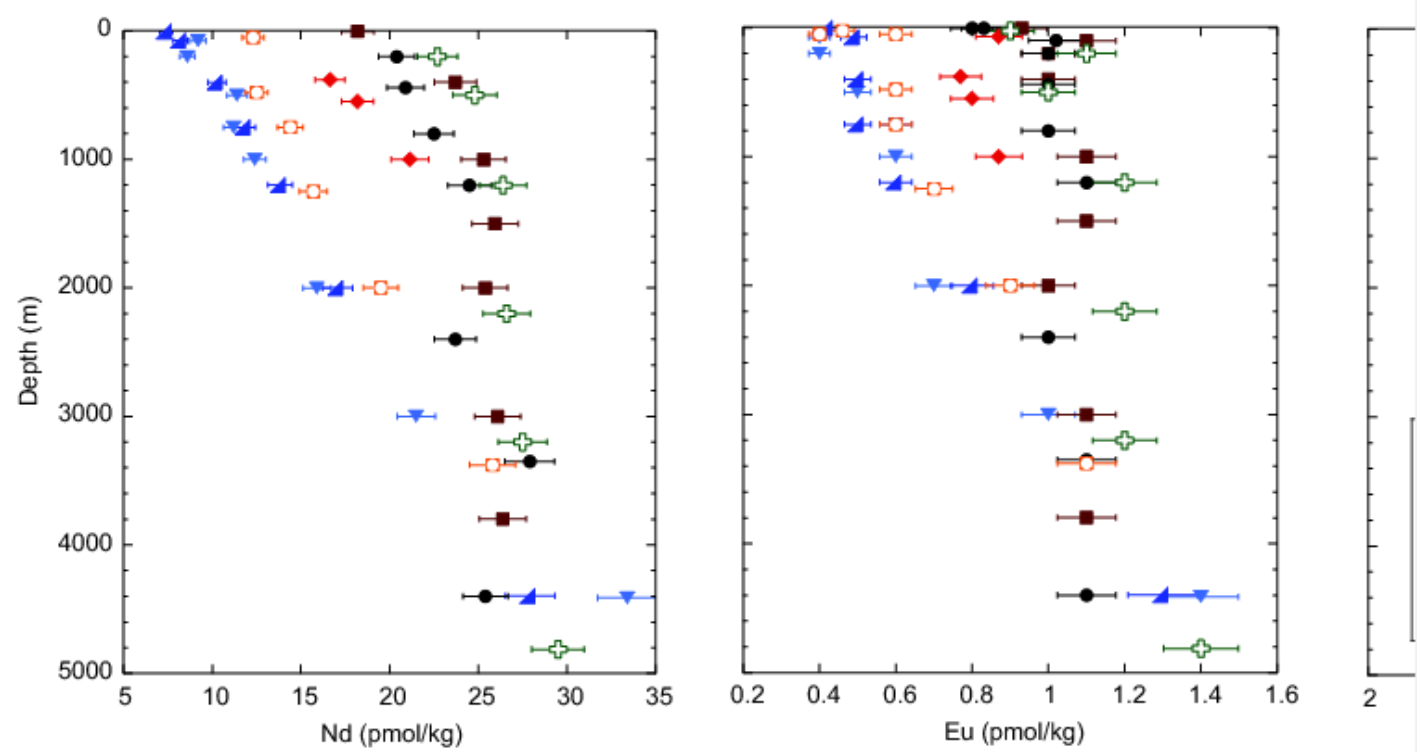

Fig. 2 

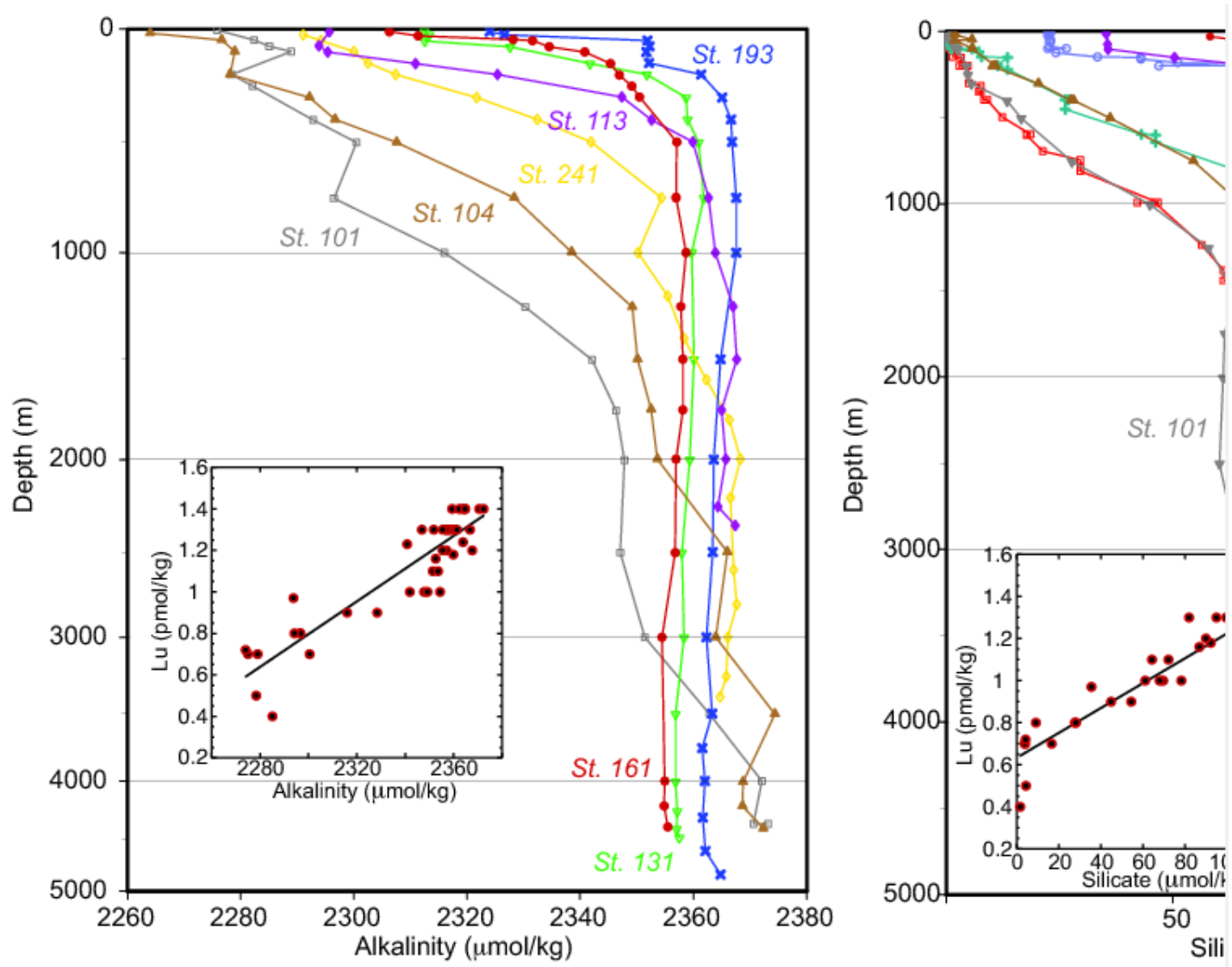

Fig. 3 

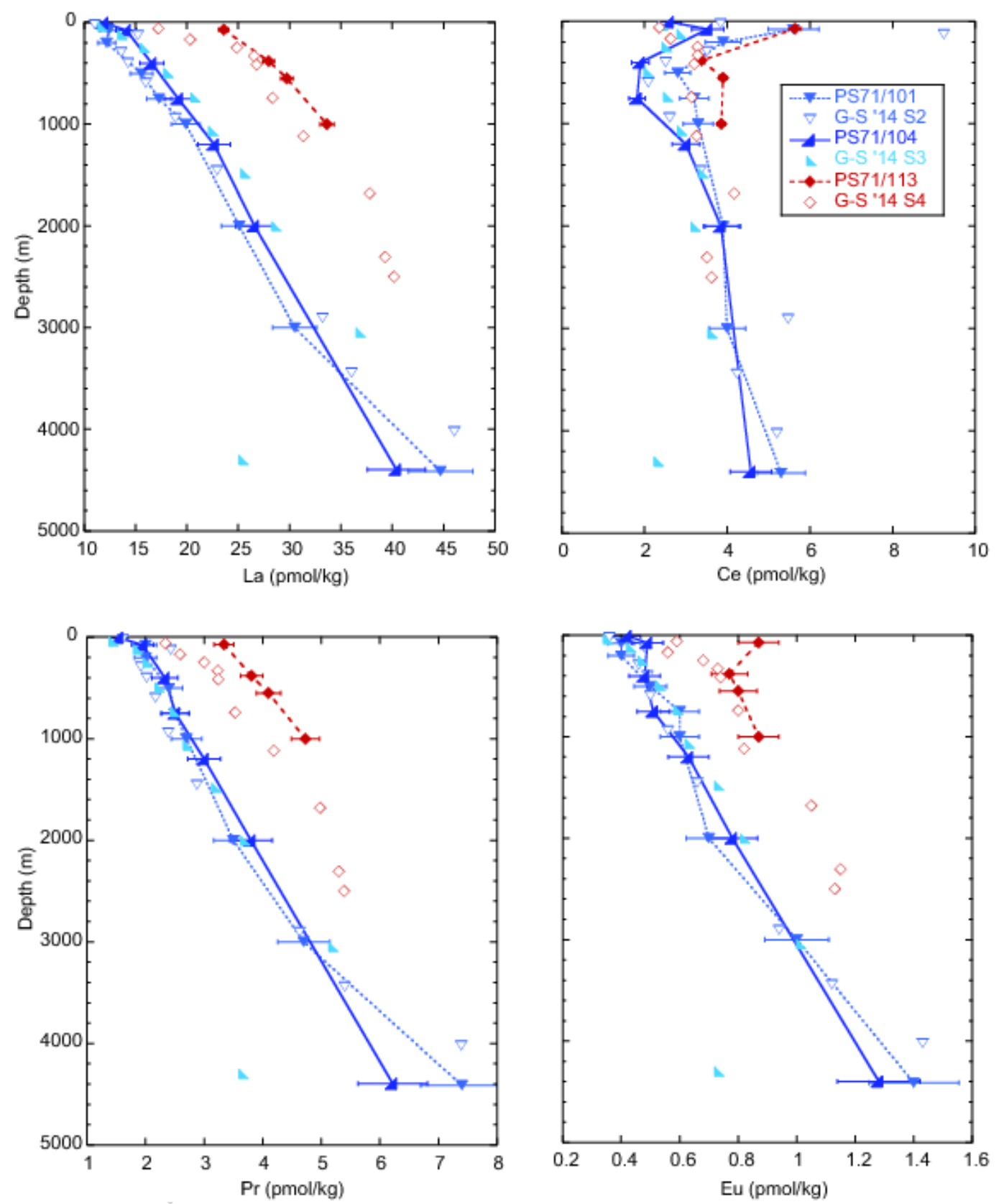

Fig. $4 a$ 

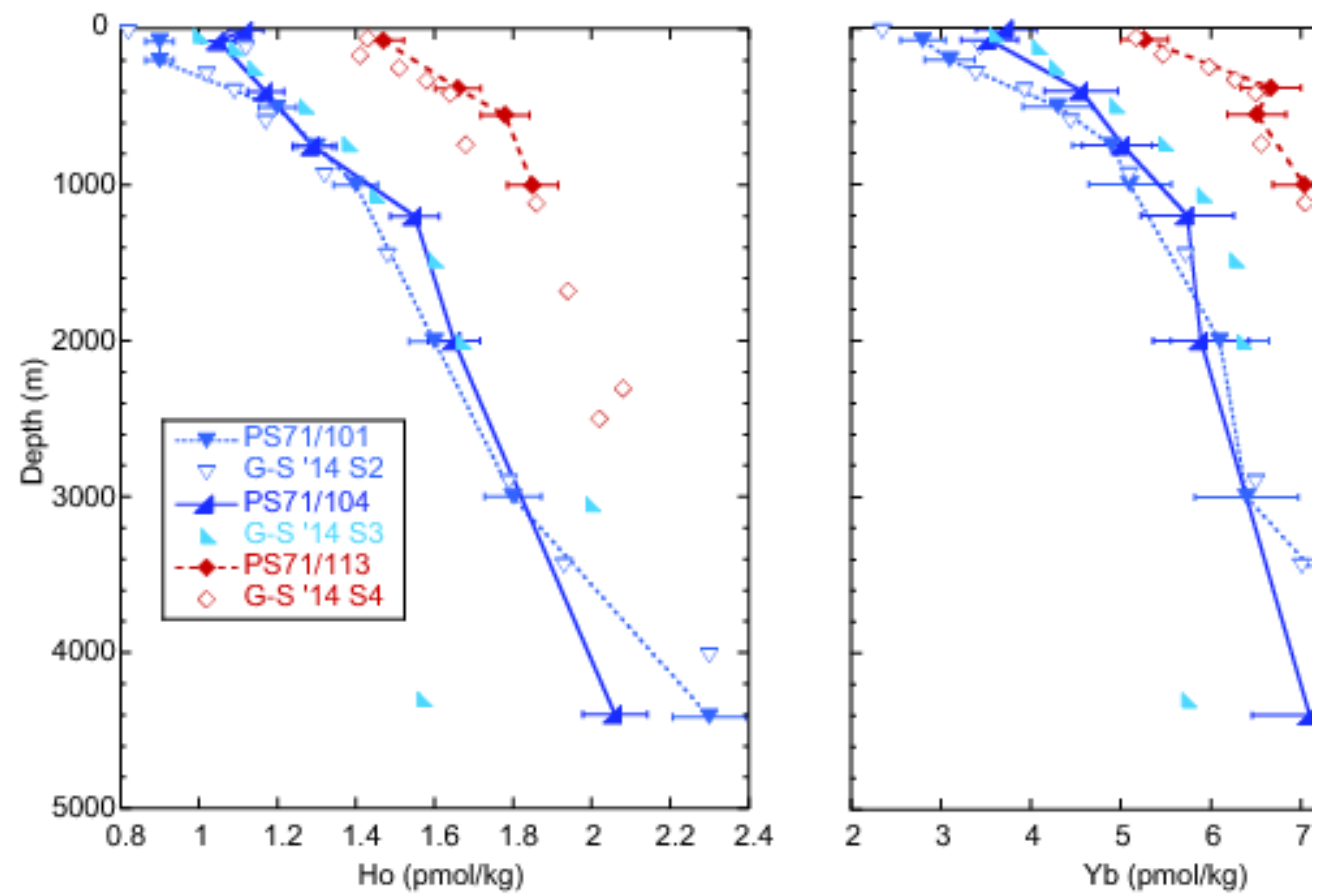

Fig. 4b 

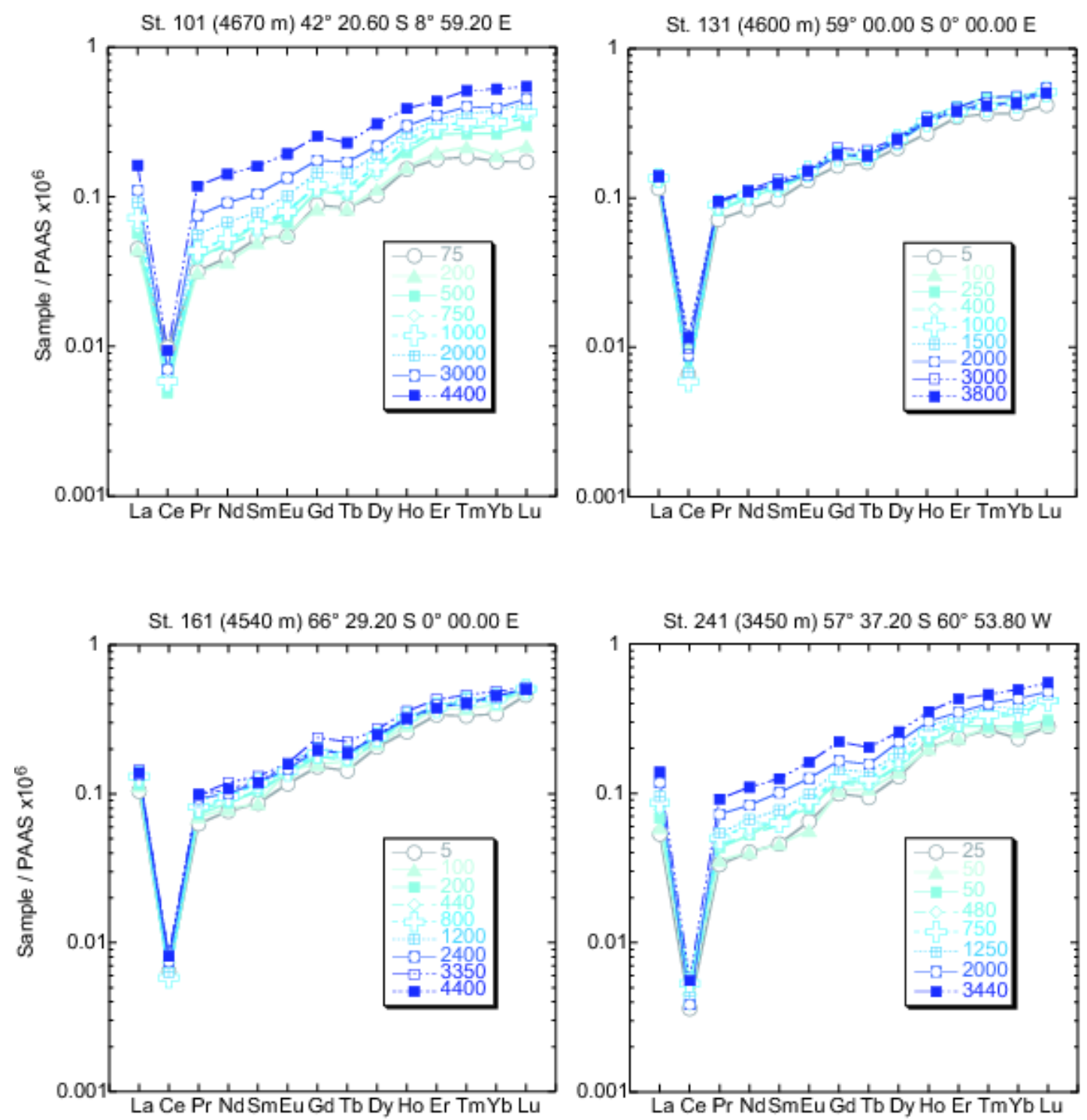

Fig. 5 

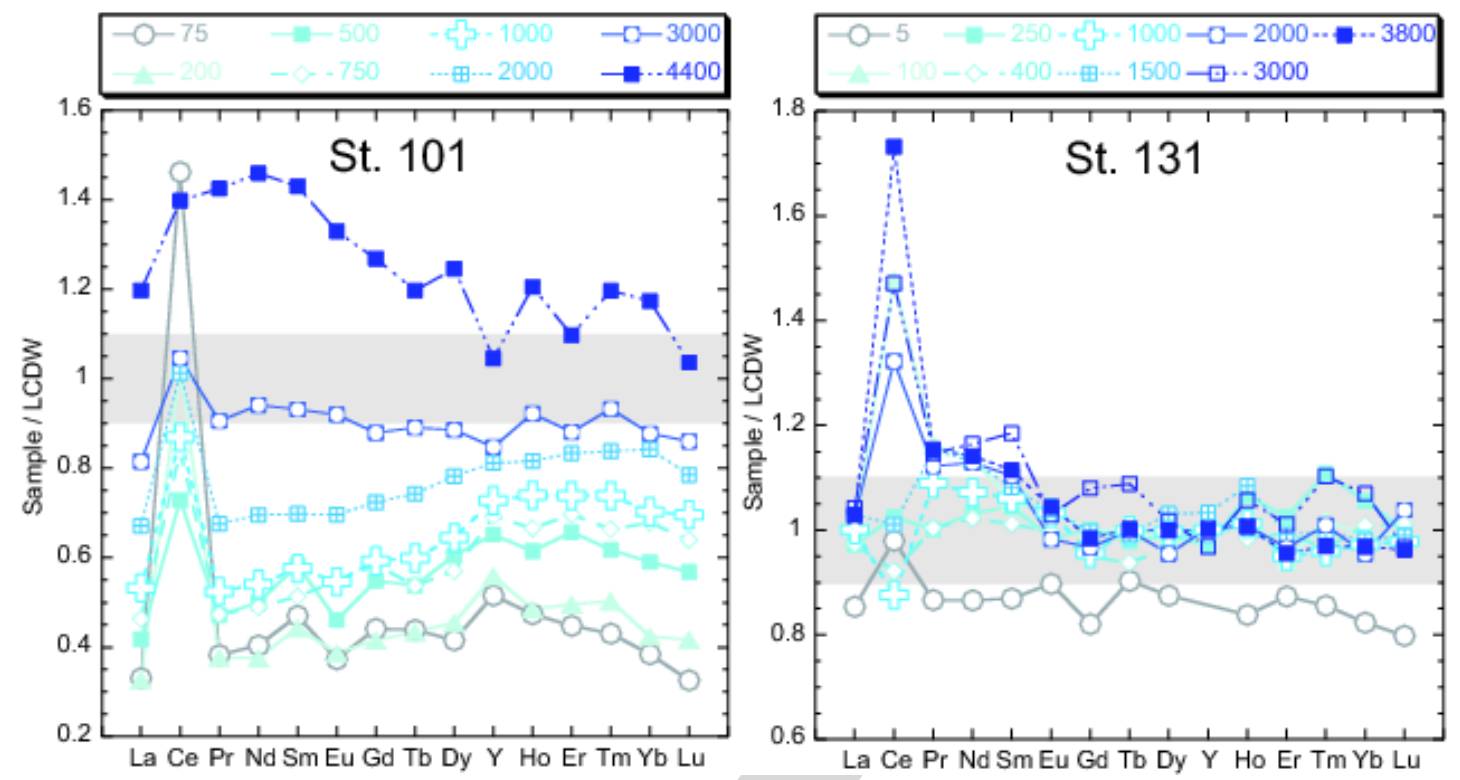

Fig. 6a 

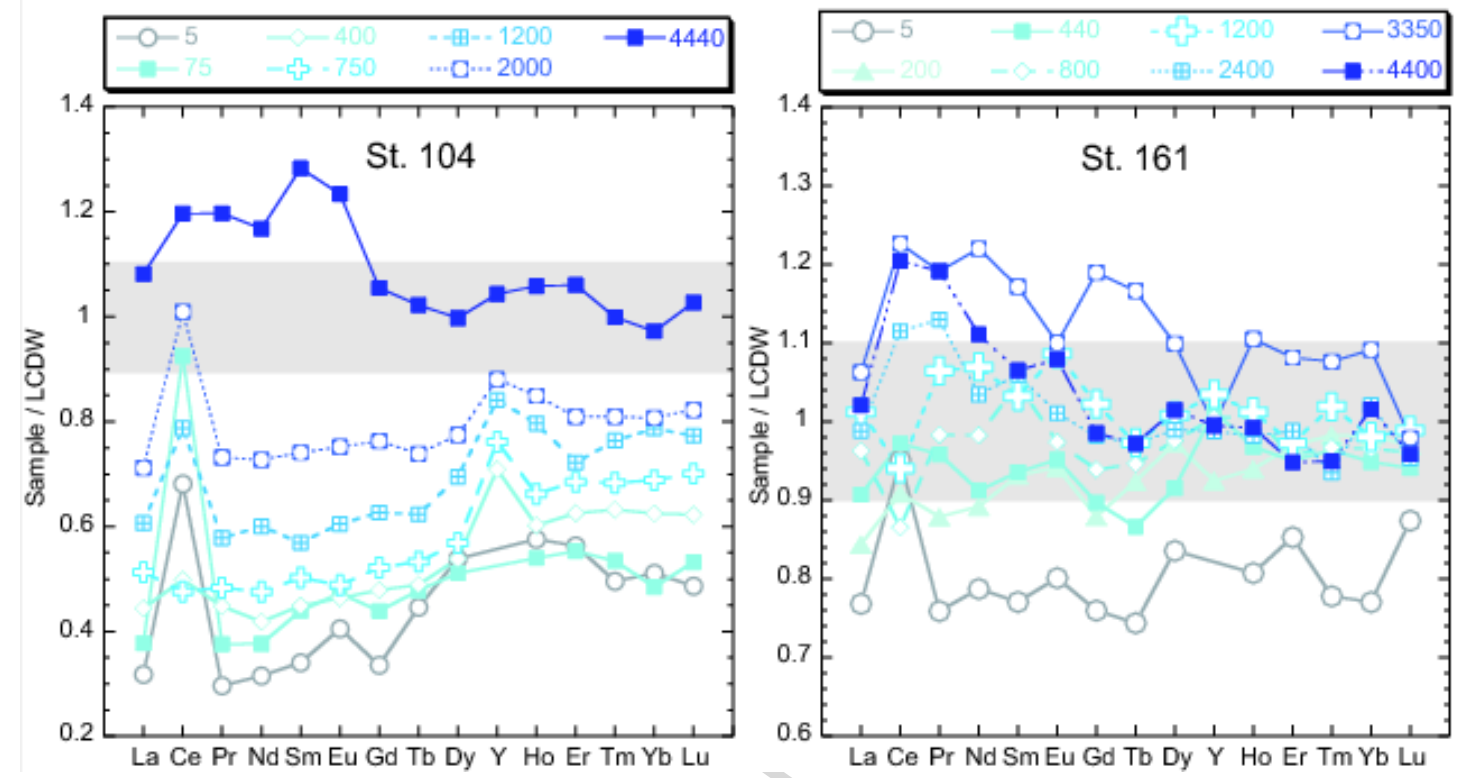

Fig. $6 b$ 

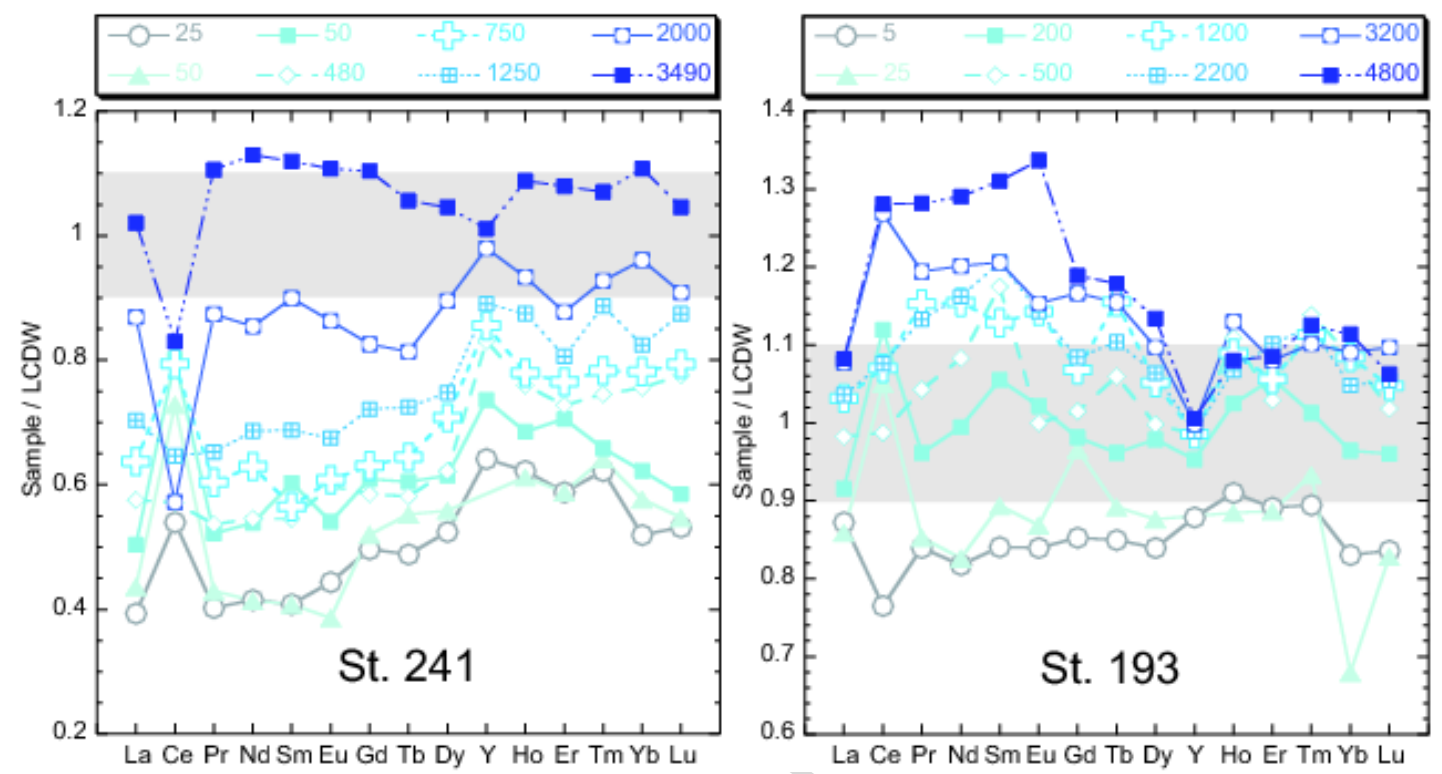

Fig. 6c 


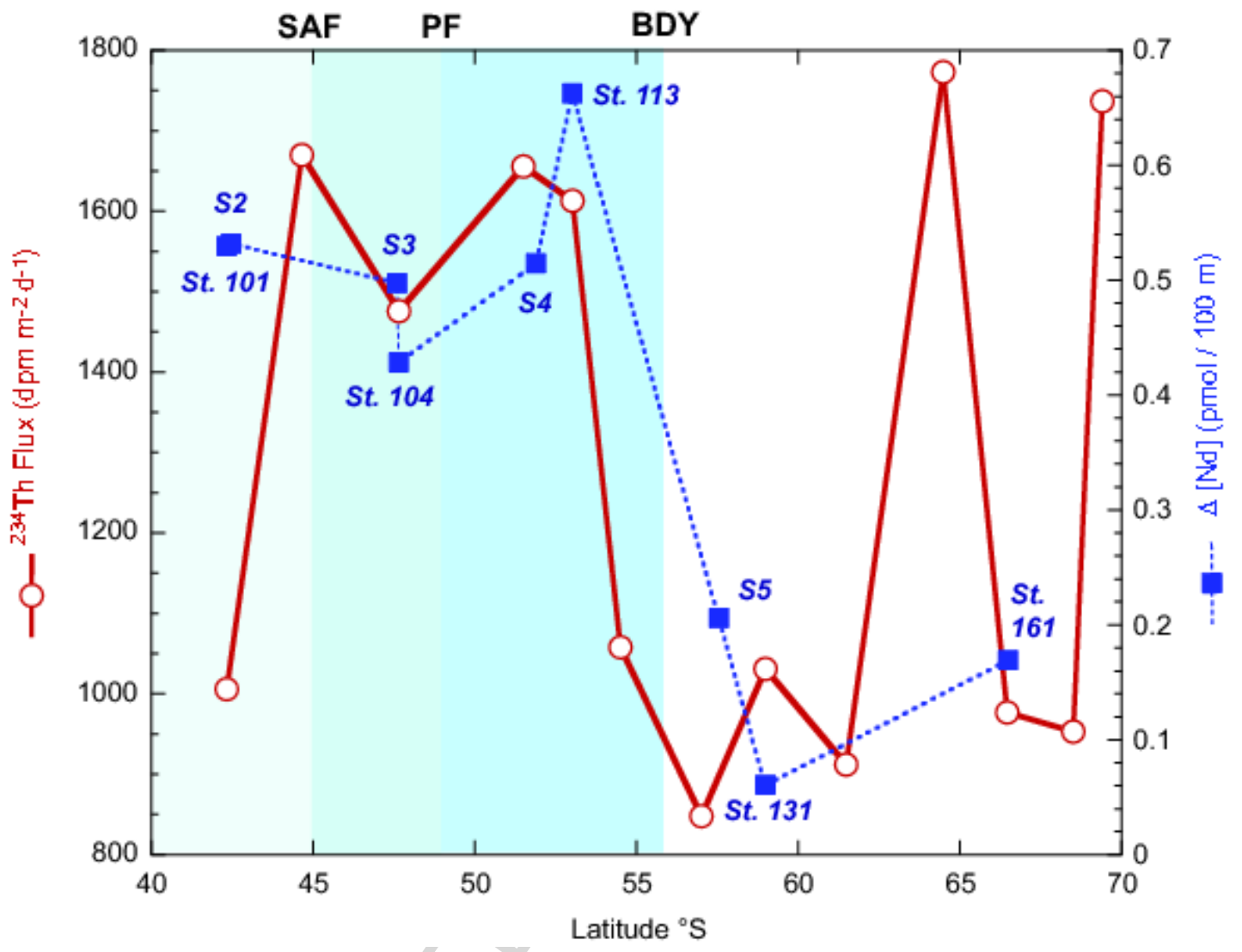

Fig. 7 


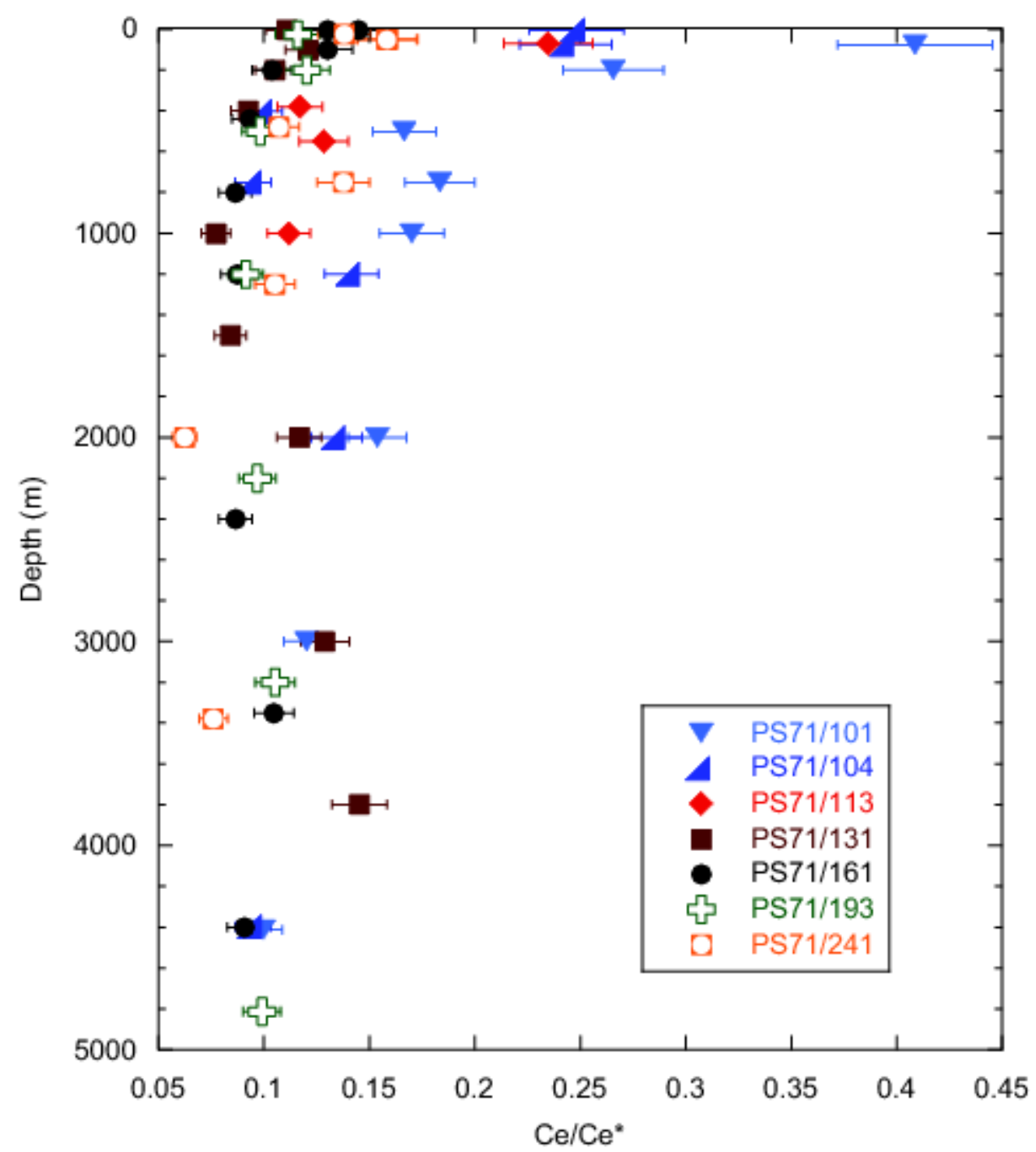

Fig. 8 

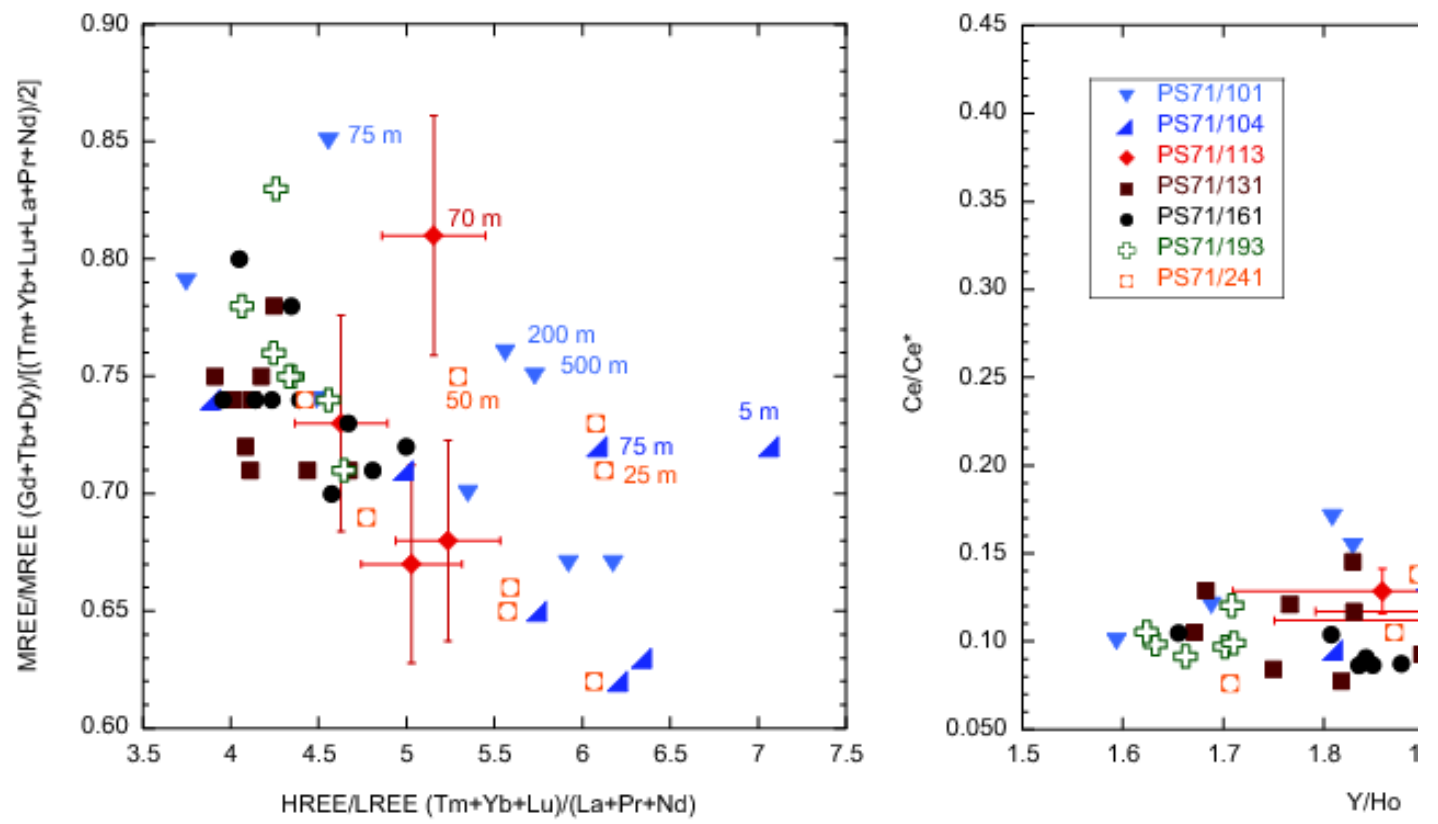

Fig. 9 